\title{
Immunotoxicity and intestinal effects of nano- and microplastics: a review of the literature
}

Nell Hirt and Mathilde Body-Malapel ${ }^{*}$ (D)

\begin{abstract}
Background: Together with poor biodegradability and insufficient recycling, the massive production and use of plastics have led to widespread environmental contamination by nano- and microplastics. These particles accumulate across ecosystems - even in the most remote habitats - and are transferred through food chains, leading to inevitable human ingestion, that adds to the highest one due to food processes and packaging.

Objective: The present review aimed at providing a comprehensive overview of current knowledge regarding the effects of nano- and microplastics on intestinal homeostasis.

Methods: We conducted a literature search focused on the in vivo effects of nano- and microplastics on gut epithelium and microbiota, as well as on immune response.

Results: Numerous animal studies have shown that exposure to nano- and microplastics leads to impairments in oxidative and inflammatory intestinal balance, and disruption of the gut's epithelial permeability. Other notable effects of nano- and microplastic exposure include dysbiosis (changes in the gut microbiota) and immune cell toxicity. Moreover, microplastics contain additives, adsorb contaminants, and may promote the growth of bacterial pathogens on their surfaces: they are potential carriers of intestinal toxicants and pathogens that can potentially lead to further adverse effects.
\end{abstract}

Conclusion: Despite the scarcity of reports directly relevant to human, this review brings together a growing body of evidence showing that nano- and microplastic exposure disturbs the gut microbiota and critical intestinal functions. Such effects may promote the development of chronic immune disorders. Further investigation of this threat to human health is warranted.

Keywords: Microplastics, Nanoplastics, Intestinal, Microbiota, Inflammation, Immunotoxicity

\footnotetext{
* Correspondence: mathilde.body@univ-lille.fr

Univ. Lille, Inserm, CHU Lille, U1286- INFINITE - Institute for Translational

Research in Inflammation, F-59000 Lille, France
}

(c) The Author(s). 2020 Open Access This article is licensed under a Creative Commons Attribution 4.0 International License, which permits use, sharing, adaptation, distribution and reproduction in any medium or format, as long as you give appropriate credit to the original author(s) and the source, provide a link to the Creative Commons licence, and indicate if changes were made. The images or other third party material in this article are included in the article's Creative Commons licence, unless indicated otherwise in a credit line to the material. If material is not included in the article's Creative Commons licence and your intended use is not permitted by statutory regulation or exceeds the permitted use, you will need to obtain permission directly from the copyright holder. To view a copy of this licence, visit http://creativecommons.org/licenses/by/4.0/ The Creative Commons Public Domain Dedication waiver (http://creativecommons.org/publicdomain/zero/1.0/) applies to the data made available in this article, unless otherwise stated in a credit line to the data. 


\section{Background}

The use of plastics has increased hugely over the past few decades. Indeed, the continuous production, use and consumption of plastics since the 1950s has created major environmental problems worldwide (Scheme 1). In 1960, half a million metric tons of plastics were released each year in the world [1]. This tonnage has since risen exponentially and has reached 359 million metric tons in 2018 [2]. In view of their low price and attractive physicochemical properties, plastics have become essential in every industry (packaging, construction, transport, etc). At present, it is almost impossible to find plasticfree goods. Plastic is used extensively in our everyday objects (packaging, cosmetics, household goods, electrical and electronic equipment, furniture, etc). Due to limited recycling and the lack of regulations limiting plastic waste, plastics (and especially nano- and microplastics) have contaminated aquatic, terrestrial and atmospheric environments worldwide. Plastics are present in our oceans, seas, rivers, and lakes, and have even reached the Arctic sea ice [3-5].

Microplastic pollution is ubiquitous in soil environments, including agricultural/farmland, greenhouse, home garden, coastal, industrial, and floodplain soils [6]. This pollution is due to the tremendous growth in plastic waste. In 2018, 25\% of the 29.1 million metric tons of post-consumer plastic waste in Europe ended up in landfills [2]. Soil microplastics come from the unsustainable use and inappropriate waste management of plastics - especially those in packaging. Moreover, microplastics are released into the soil by agricultural processes [7]; the use of plastic mulches and the application of sewage sludge to fields are major sources of soil microplastics. In order to prevent microplastics from entering the aquatic environment, wastewater treatment plants remove microplastics from the wastewater but thus concentrate them in the sludge subsequently used as a fertilizer on agricultural soils [8].
In the marine environment, plastic debris can be found on the sea floor, surface and shoreline. Eriksen et al. estimated in 2014 that at least 5.25 trillion plastic particles including 35,500 metric tons of microplastics were floating at sea [9]. It has been estimated that $80 \%$ of the plastic pollution in the oceans and seas comes from land [10] and the estimated amount of land-based plastic debris entering the ocean is between 4.8 and 12.7 million metric tons per years [11]. Microplastics are detected in freshwater, including lakes, rivers, and groundwater. These particles come mainly from urban pollution but also from shipping, fisheries, tourism, oil and gas platforms, wastewater treatment plants, discharged personal health care products, textiles, and packaging [12]. Rochman et al. (2015) calculated that in 2015, 8 trillion microbeads per day were emitted into aquatic habitats in the United States [13].

Lastly, the atmosphere is a new recognized vehicle through which microplastics enter the wider environment $[14,15]$. Microplastics have been measured in atmospheric fallout in both megacities [16, 17] and sparsely inhabited areas [18]. Suspended atmospheric microplastics have been also repeatedly detected in indoor air [19, 20].

The omnipresence of microplastics in the environment leads to human exposure largely by ingestion but also by inhalation and dermal contact [21]. This exposure is a cause of concern for potential long-term health hazards. Recent research has highlighted the possible adverse effects of nano- and microplastic exposure on intestinal homeostasis, gut microbiota and immune response. Here, we review this emerging field. Firstly, nano- and microplastics were briefly defined, then the pathways through which they can interact with the intestine and the immune system were described. Afterwards, studies of in vivo exposure to nano -and microplastics on the gut epithelium, the intestinal microbiota, and the immune system were detailed. The potential of

\begin{tabular}{|c|c|c|}
\hline & $\begin{array}{l}\mathbf{5} \text { statistics on plastic pollution } \\
\mathbf{0 , 5} \text { million } \\
\text { metric ton released in } \\
1950[1] \\
360 \text { million } \\
\text { metric tons released in } \\
2018[2] \\
35,500 \text { metric tons } \\
\text { of microplastics afloat at sea } \\
{[9]} \\
80 \text { percent } \\
\text { of plastic pollution (oceans and seas) come from land }[10] \\
8 \text { trillion } \\
\text { microbeads emitted into aquatic habitats per day }[13] \\
\text { ence of plastics }\end{array}$ & $\begin{array}{l}\quad \text { Plastics end-use markets [2] } \\
\\
\quad \text { 39.9\% packaging } \\
\checkmark 19.8 \% \text { building and construction } \\
\quad 9.9 \% \text { automotive } \\
6.2 \% \text { electrical and electronic } \\
\checkmark 4.1 \% \text { household, leisure and sport } \\
\checkmark 3.4 \% \text { agriculture } \\
\quad 16.7 \% \text { others (appliances, mechanica, engineering, furniture, } \\
\text { medical, etc) }\end{array}$ \\
\hline
\end{tabular}


microplastics as carriers of intestinal toxics and pathogens was emphasized. Lastly, current research perspectives and future needs were discussed.

\section{Definitions of MICROPLASTICS and NANOPLASTICS}

The term "plastics" refers to any material containing a high polymer as an essential ingredient and has been discovered since the beginning of the twentieth century [22] (Scheme 2). Plastics consist of an assembly of polymers (polyethylene (PE), polypropylene (PP), polystyrene (PS), polyvinyl chloride (PVC), polyethylene terephthalate (PET), polycarbonate (PC), poly methyl methacrylate (PMMA), polyurethane (PU), etc) and additives (stabilizers, flame retardants, plasticizers, fillers, and pigments) that increase their performance [2, 23]. Plastic particles can be divided into two categories: primary particles are contained in manufactured products (personal health care products, etc) whereas secondary particles come from the degradation of products (packaging, clothes, etc). The degradation of plastics (photodegradation, oxidation, hydrolytic degradation, biodegradation) produces different forms and sizes of debris; nanoplastics $(\leq 0.1 \mu \mathrm{m})$, microplastics $(<5 \mathrm{~mm})$, mesoplastics $(0.5-5 \mathrm{~cm})$, macroplastics $(5-50 \mathrm{~cm})$, and megaplastics $(>50 \mathrm{~cm})$ [24].

The term "microplastics" was used for the first time by Thompson et al. (2004) [25]. Microplastics are usually defined as "small ubiquitous plastic particles $<5 \mathrm{~mm}$ in diameter", but there is currently no consensus on the definition of microplastics [26, 27]. However, they can be characterized with regard to their size, shape and even by chemical composition. For example, microplastics can be subcategorized as a function of the shape as beads (in personal health care products), nurdles (preproduction of plastic beads), fibres (textile industry), foams (food industry, packaging) and fragments (degradation of plastic products), and also pellets, filaments, films, etc. Further categorization by shape has been suggested (e.g., cylindrical, disk, flat, ovoid, spheruloid, elongated, rounded, irregular, etc) [26] .

As is the case for microplastics, there is no internationally agreed definition of a nanoplastic. The European Food Safety Authority (EFSA) has defined nanoplastics as "a natural, incidental or manufactured material containing particles, in an unbound state or as an aggregate or as an agglomerate and where, for 50\% or more of the particles in the number size distribution, one or more external dimensions is in the size range of $1 \mathrm{~nm}-100 \mathrm{~nm}$ ". However the upper size limit for nanoplastics is $100 \mathrm{~nm}$ in some definitions and 1000 $\mathrm{nm}$ in others [28]. Here, we adopted the value of 100 $\mathrm{nm}$ as the threshold between nanoplastics and microplastics. As is the case for microplastics, nanoplastics can originate from engineered material or can be produced by the fragmentation of larger plastic particles. Unfortunately, nanoplastics are difficult to detect. There are currently a number of methodological obstacles to the characterization and quantification of nanosized particles [29].

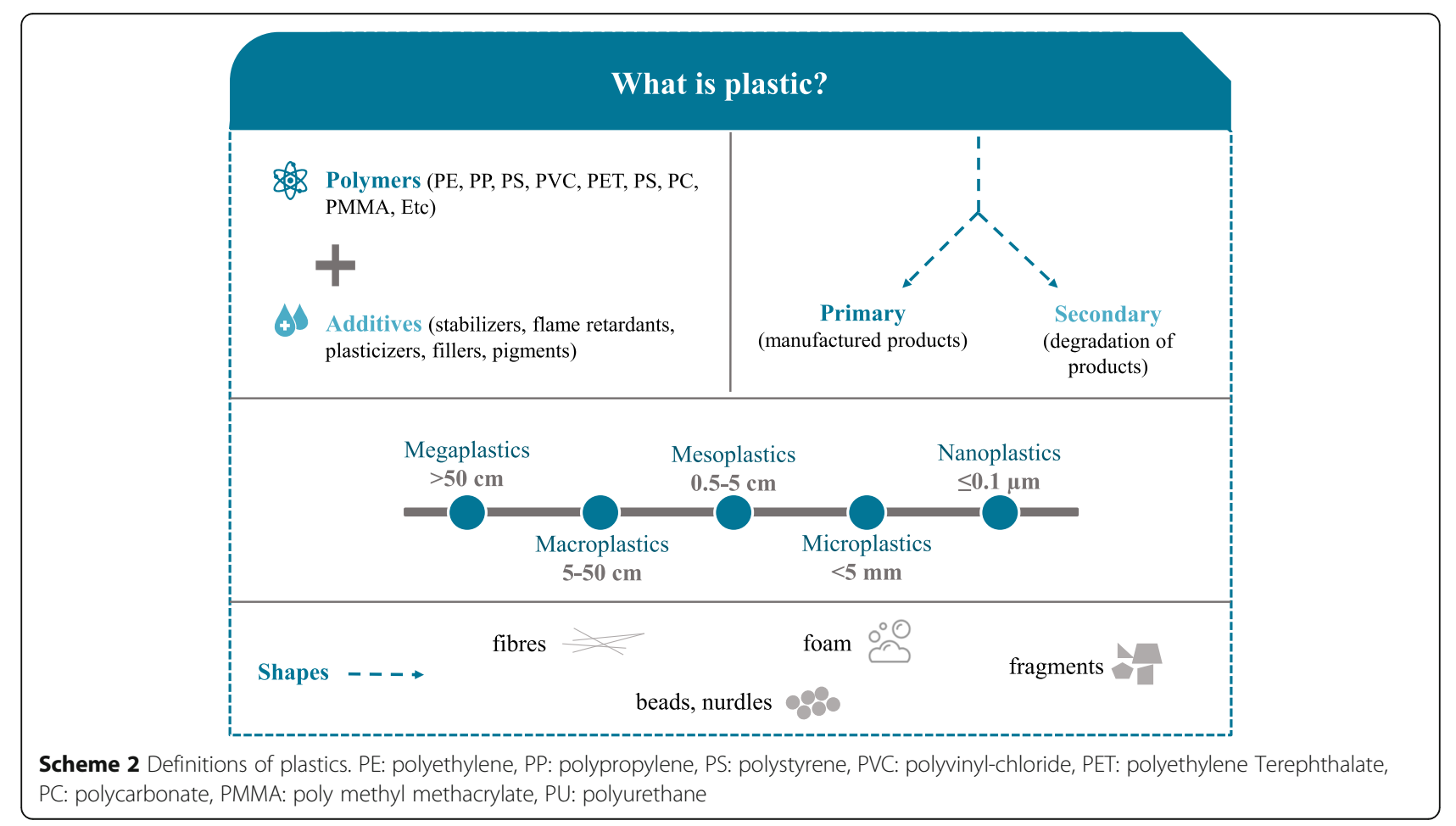




\section{Human exposure to NANO- and MICROPLASTICS} Human exposure to microplastics through ingestion The human ingestion of microplastics was revealed by the detection of microplastics in several dietary products (Scheme 3). Firstly, microplastics are ubiquitous in surface water, groundwater and wastewater [30]. Plastics are also found in drinking water and this issue has been reviewed recently [31, 32]. Koelmans et al. reported on the types of plastics found in freshwater (in decreasing order of frequency): fragments (35\%), fibres (25\%), films, foams, pellets, spheres, lines, beads, flakes, sheets, granules, paints, foils and nurdles. Overall, the polymers most frequently detected by researchers are $\mathrm{PE} \approx \mathrm{PP}>$ PS $>$ PVC $>$ PET, followed by polyamide (PA), acrylic or acrylic-related compounds, polyesters and PMMA. Despite the removal of microplastics by various water treatment processes, microplastics are also detected in tap water [33]. In Kosuth et al.'s study of 159 samples of tap water from all over the world, $81 \%$ contained microplastics; the mean concentration was 5.45 particles/L [34]. In an analysis of tap water samples in China, the lowest microplastic particle count measured was 440/L. Most of these particles were smaller than $50 \mu \mathrm{m}$ fragments (followed by fibres and spheres) and composed mainly of PE and PP [35]. Microplastic particles were also detected in mineral water contained in both plastic bottles and glass bottles. The literature data on microplastics in mineral water were compiled recently [36]. The overall reported concentrations of microplastics were $0.6 \mu \mathrm{g} / \mathrm{L}$ [37] and $7.3 \mu \mathrm{g} / \mathrm{L}$ [38] in multi-use PET bottles, and $0.1 \mu \mathrm{g} / \mathrm{L}$ [37] and $1.8 \mu \mathrm{g} / \mathrm{L}$ [38] in single-use PET bottles. The concentrations in water in glass bottles were even higher $(2.6 \mu \mathrm{g} / \mathrm{L}$ [37] and $8.7 \mu \mathrm{g} / \mathrm{L}$ [38]). The overall particle number ranged from 14 to 6290 particles/L [36]. Particles smaller than $5 \mu \mathrm{m}$ accounted for approximately
96\% of the total in PET bottles and 78\% in glass bottles [39]. In a recent analysis of microplastics in Thailand, there were 140 particles/L in water in PET bottles, 52 particles/L in water in glass bottles, 81, 26 and 12 particles/L for the $6.5-20 \mu \mathrm{m}, 20-50 \mu \mathrm{m}$, and $>50 \mu \mathrm{m}$ diameter sizes [40]. The estimated maximum annual uptake by human adults is 458,000 microplastic particles for tap water and 3,569,000 microplastic particles for bottled water [32].

Given the presence of microplastics in the oceans, these particles are also detected in seafood products [41, 42]. Indeed, some of the 220 species found to ingest microplastic debris in natura (such as mussels, oysters, clams, common shrimps, etc) are of commercial importance for fisheries and aquaculture [43]. In Hantoro et al.'s review of studies of microplastics in seafood, it was estimated that the human intake can attain $66 \times 10^{3}$, $28 \times 10^{3}$ and $36 \times 10^{3}$ particles/day through fish, crustacean, and mollusk consumption, respectively [44].

Furthermore, qualitative and quantitative measurements of microplastics have been reported for other food products, such as honey and sugar. In samples of these basic products collected in Europe (Germany, France, Italy, and Spain) and Mexico, the fibre content per $\mathrm{kg}$ was 166 for honey and 217 for sugar [45].

Microplastic contamination has also been detected in sea salt originating from various countries worldwide [34, 46-49], and these data have been reviewed by Toussaint et al. [26]. For example, 550-681 particles $/ \mathrm{kg}$ were detected in sea salt samples collected across China, [46]. The majority of the particles (55\%) measured less than $200 \mu \mathrm{m}$ in diameter. Fragments and fibres were more prevalent than pellets and sheets. The most common microplastics were PET, followed by PE and cellophane.
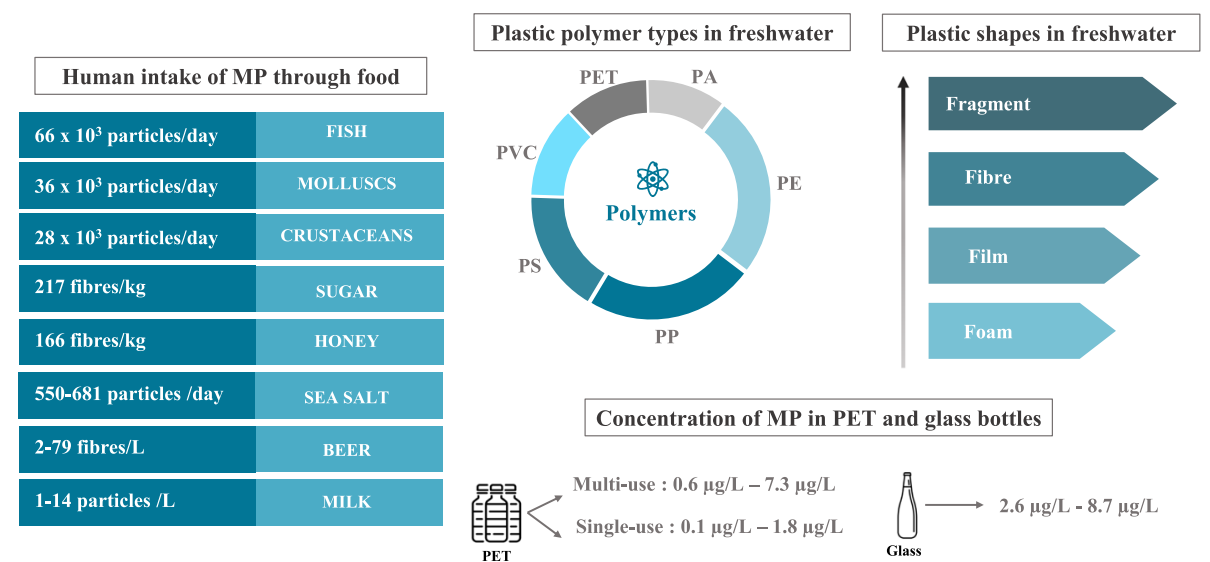

Scheme 3 Human ingestion of microplastics. PE: polyethylene, PP: polypropylene, PS: polystyrene, PVC: polyvinyl chloride, PET: polyethylene terephthalate, PA: polyamide. Data on plastic polymers and shapes in freshwater are based on the number of studies reporting the presence of a particular polymer or shape of microplastic particles in freshwater. Adapted from Koelmans, Water Research 155 (2019) $410-422$ 
Furthermore, Liebezeit et al. analyzed the content of microplastics in German beers [50]. Microplastic contamination was found in all cases, with counts ranging from 2 to 79 fibres/L, from 12 to 109 fragments/L and from 2 to 66 granules/L. The relative contributions ranged from 5 to $71 \%$ for granular material, from 14 to $87 \%$ for fragments and from 3 to $57 \%$ for fibres.

Microplastics have been also detected in cow milk samples for adults and children. All samples contained microplastic particles, with differences in the amounts (1 to 14 particles/L) [51]. Of the total detected microplastics, $97.5 \%$ were fibres and $2.5 \%$ were fragments: microplastics $<0.5 \mathrm{~mm}$ were dominant $(40 \%)$ followed by the sizes $0.5-1 \mathrm{~mm}(28 \%)$ and $1-2 \mathrm{~mm}(25 \%)$.

Lastly, many researchers have attempted to estimate the yearly human exposure to microplastics, However, interstudy differences in the types of plastic and the experimental methods mean that these estimations vary markedly [26]. In such a context, another way to estimate human contamination is probably to measure the amount of plastic in human feces. This is what Schwabl et al. did in a recent study of stools samples from 8 healthy volunteers: the mean number microplastic particles (from 50 to $500 \mu \mathrm{m}$ in size) was 20 per $10 \mathrm{~g}$. Nine types of plastic were detected, with PP and PET being the most abundant. Based on these results and an average production of $128 \mathrm{~g}$ of feces per day per person, the researchers estimate that the annual discharge of microplastic particles in the feces (reflecting at least in part the equivalent human body exposure) was over 90,000 [39].

\section{Other routes of human exposure to nano- and microplastics}

Human exposure to microplastics also occurs through inhalation, because microplastics are present in the indoor and outdoor air [52]. The sources of airborne microplastics have been reviewed recently [14, 15]. Synthetic textiles, the erosion of synthetic rubber tires, and city dust are thought to be the most important sources of airborne microplastics. Fibres were the dominant shape, and PP, PE, PS and PET were the dominant polymer components of microplastics in atmospheric fallout. Individual human exposure by inhalation has been estimated at 26 to 130 airborne microplastic particles a day [14].

Lastly, microplastics reach humans by dermal contact. Microplastic beads are included in the composition of facial cleansers, facial scrubs, and toothpaste, where they are used as exfoliators for the skin and teeth [53]. A recent Chinese study has identified personal care products containing microplastics. Overall, $7.1 \%$ of facial cleansers contained microplastics, with a mean \pm standard deviation content of $25.04 \pm 10.69 \mathrm{mg}$ microplastics/g and mean size of $313 \pm 130 \mu \mathrm{m}$. The majority of these microplastics were made of PE [54]. Microplastic beads are also used to regulate the viscosity of films, condition the skin, and stabilize emulsions: they are included into a wide range of products, such as soaps, shampoos, deodorants, wrinkle creams, moisturizers, shaving creams, sunscreen lotions, facial masks, lipsticks, eye shadows, and children's bubble bath [55]. The glitters which are used in significant volumes in make-up (and also craft activities and textile products) are usually PET-containing plastics [56]. Moreover, the microbeads used in consumer products (such as scrubs and shampoos) are processed by mechanical means, which may lead to their fragmentation into potentially more hazardous nanoplastics. The presence of nanoplastics has been confirmed in personal care products containing PE microbeads [57].

\section{Relationships between NANO- and MICROPLASTICS, the intestinal mucosa, and the immune system}

Many studies of various species have shown that ingested microplastics accumulate in the gut of various species [58-61]. After a five-day oral course of $60 \mathrm{~nm}$ PS nanoparticles in rats, approximatively $10 \%$ of the dose was found in the gastrointestinal tract [62]. Not much is known on the distribution of nano- and microplastics after ingestion. Based on in vitro and in vivo data, knowledge on the uptake of nano- and microplastics has been reviewed by the European Food Safety Authority [63]. Microplastics with a greatest dimension $>150 \mu \mathrm{m}$ are not absorbed, they remain bound to the intestinal mucus layer and come into direct contact with the apical part of intestinal epithelial cells. This may lead to inflammation of the gut and local effects on the immune system. The smaller particles (greatest dimension $<150 \mu \mathrm{m}$ ) can cross the mucus barrier. Indeed, several mechanisms result in the size-dependent uptake of nano- and microparticles: (i) endocytosis through enterocytes, (ii) transcytosis through microfold cells (also referred to as M-cells, a specific subset of intestinal epithelial cells in gut-associated lymphoid tissue), (iii) persorption (namely the passage through "gaps" at the villous tip, following the loss of enterocytes), and (iv) paracellular uptake [64]. Uptake of microparticles by endocytosis, transcytosis and paracellular diffusion between enterocytes has been observed in rodents without any disruption of the intestinal barrier $[65,66]$. Peyer's patches have a high proportion of M-cells and constitute the main site of microplastic absorption [67]. The intestinal uptake of microparticles is not very efficient: in one study, only $0.3 \%$ orally administrated latex particles (greatest dimension: $2 \mu \mathrm{m}$ ) crossed the epithelium [68]. Despite this low level, intestinal absorption of particles may lead to systemic toxicologically relevant exposure. The small size of nanoplastics allows them to penetrate deeply into organs. Data from animal studies have shown that once 
absorbed, nanoplastics can distribute to the liver, spleen, heart, lungs, thymus, reproductive organs, kidney, and even the brain (i.e. they cross the blood-brain barrier [69]) [63].

It must also be borne in mind that airborne microplastics may also have an impact on the digestive tract and the immune system. It is known that among airborne particles, the smallest particles (i.e. the inhalable fraction) are absorbed via the pulmonary epithelium [70, 71]. They reach the systemic circulation and exert an immune effect on the so called gut-lung axis [72]. A proportion of the larger particles (the extrathoracic fraction) is transported to the gastrointestinal tract by mucociliary clearance, where it undergoes the fate of ingested particles. Hence, depending of the particle size, both ingested and inhaled plastics are able to interact with intestinal tissues, reach the bloodstream and (potentially) dysregulate the immune response.

\section{Effects of exposure to NANO- and MICROPLASTICS on the gut epithelium}

Several in vivo studies have explored the effects of nanoand microplastic exposure on the gut epithelium (Table 1). Intestinal impact has been demonstrated in invertebrates. In $C$ elegans nematode, exposure to a cocktail of microplastics (PE, PP, PVC and PS particles, from 0.1 to $70 \mu \mathrm{m}$ in size and at a concentration of 5 $\mathrm{mg} \mathrm{m}^{-2}$, for 2 days) was associated with a significant reducttion in intestinal calcium levels and elevated intestinal expression of the enzyme glutathione S-transferase 4 , suggesting that intestinal oxidative damage is a key mechanism in microplastic toxicity [74]. In Artemia parthenogenetica zooplankton larvae, exposure to low levels of PS microspheres $(10 \mu \mathrm{m}, 10$ particles $/ \mathrm{mL}$, over 14 days) was associated with the progression of cellular deformations and the enterocyte decomposition [75]. In the mussel Mytilus spp, exposure to PS microbeads (2 and $6 \mu \mathrm{m}, 32 \mu \mathrm{g} / \mathrm{L}$, for 7 days) also resulted in alterations in the oxidative balance in the digestive gland (a reduction in catalase and glutathione reductase activities, and in lipid peroxidation) [76]. Another study of exposure of mussels to PS beads but on the nano scale level revealed that PS nanoplastics $(110 \mathrm{~nm}, 0.05$ to $50 \mathrm{mg} / \mathrm{L}$, for $96 \mathrm{~h}$ ) increased $H s p 70$ mRNA levels, total oxidant status, total antioxidant capacity, and lipid peroxidation in the digestive gland [77]. Exposure of mussels to a mixture of PE and PS microbeads $(<400 \mu \mathrm{m}$, for 10 days $)$ was associated with lower glutathione $\mathrm{S}$ transferase and superoxide dismutase activities (at $100 \mu \mathrm{g} / \mathrm{L}$ ) and greater superoxide dismutase and catalase activities (at 0.008 and $10 \mu \mathrm{g} / \mathrm{L}$ ) [78].

The intestinal effects of oral exposure to microplastics have been also demonstrated in vertebrates, namely in aquatic vertebrates and in mice. In aquatic vertebrates, several studies have explored the effects of PS. In the rainbow trout, exposure to PS beads $(100-400 \mu \mathrm{m}, 10$ $\mathrm{mg} /$ fish/day for 4 weeks) was not associated with any variation in paracellular permeability, ion transport, and intestinal tight junction and cytokines mRNA expression [79]. In juvenile guppies, exposure to PS microbeads (32-40 $\mu \mathrm{m}, 100$ and $1000 \mu \mathrm{g} / \mathrm{L}$ for 28 days) decreased digestive enzymes activity, induced goblet cells enlargement, and gut TNF $\alpha$ (Tumor Necrosis Factor $\alpha$ ), IFN $\gamma$ (Interferon $\gamma$ ) and IL-6 (Interleukin-6) secretion [80]. In juvenile intertidal fish Girella laevifrons, histological analyses of the intestine showed that the exposure of microplastics ( $8 \mu \mathrm{m}$ poly (styrene-co-divinylbenzene), 0.02 and $0.2 \mathrm{~g} / \mathrm{g}$ of food, once a week for 45 days) led to leukocyte infiltration, hyperemia, and the loss of villi and crypt cells [81]. In the juvenile large yellow croaker Larimichthys crocea, exposure to PS nanospheres $(100 \mathrm{~nm}$, $10^{4}$ and $10^{6}$ particles/L, for 14 days) was associated with lower activities of several digestive enzymes (lipase, trypsin, and lysozyme) [82]. Another study assessed the effects of both nano-sized $(50 \mathrm{~nm})$ and micro-sized $(45 \mu \mathrm{m})$ PS particles $(2.5 \mu \mathrm{g} / \mathrm{mL}$, for 14 days $)$ in marine medaka Oryzias melastigma: some modifications were shared between both sizes of particles, such as the increase of mucus secretion and gut diamine oxidase levels. On the contrary, gut levels of oxidative stress enzymes were modified in opposite ways between nanosized and micro-sized particles [83].

Moreover, several studies have explored the intestinal effects of PS exposure on zebrafish. In one study, exposure to PS beads $(0.5 \mu \mathrm{m}, 1000 \mathrm{mg} / \mathrm{L}$, for 14 days $)$ increased both gut mRNA and protein levels of the major proinflammatory cytokines IL1 $\alpha$, IL1 $\beta$ and IFN [84]. At a 10-fold-lower dosage or after exposure to larger PS beads $(50 \mu \mathrm{m})$ under the same experimental conditions, these upregulations were not observed [84]. In another study, exposure to PS beads $(5 \mu \mathrm{m}, 50$ and $500 \mu \mathrm{g} / \mathrm{L}$, for 21 days) enhanced catalase and superoxide dismutase activities, reflecting an excessive oxidative stress. The exposure was also associated with lower levels of the antioxidant enzyme diamine oxidase and of D-lactate, a fermentation metabolite produced by various bacteria in the gut, which reflected an increase in intestinal permeability [85]. Lastly, single-cell RNA sequencing was used to determine the intestine-specific effects of PS nano-and microplastic beads $(100 \mathrm{~nm}, 5$ and $200 \mu \mathrm{m}, 500 \mu \mathrm{g} / \mathrm{L}$, for 21 days) in the zebrafish [86]. The transcriptome profiles revealed dysfunctions of intestinal cell populations, e.g. immune response of enterocytes, phagocytes and lymphocytes, detoxification/antioxidant capacity of enterocytes, cell chemotaxis of secretory cells. These effects were dependent on the particle size and specific of the intestinal cell population. They were 
Table 1 Overview of in vivo studies of the effects of nano- and microplastic exposure on the gut epithelium. ${ }^{*}$ This has been calculated by the authors based on Bachmanov AA et al. Behav Genet 2002 [73]

\begin{tabular}{|c|c|c|c|c|c|c|}
\hline Reference & Nano-microplastics & Dosage & $\begin{array}{l}\text { Duration } \\
\text { of exposure }\end{array}$ & $\begin{array}{l}\text { Route of } \\
\text { exposure }\end{array}$ & Species & $\begin{array}{l}\text { Observed effects related to the } \\
\text { gut epithelium }\end{array}$ \\
\hline \multicolumn{7}{|l|}{ Invertebrates } \\
\hline $\begin{array}{l}\text { Lei et al., } \\
\text { Sci } \\
\text { Total Environ. } \\
2018[74]\end{array}$ & $\begin{array}{l}\text { Polyamides, } \\
\text { polyethylene, } \\
\text { polypropylene, } \\
\text { polyvinyl chloride } \\
\text { and polystyrene } \\
0.1 \text { to } 70 \mu \mathrm{m}\end{array}$ & $5 \mathrm{mg} \mathrm{m}^{-2}$ & 2 days & $\begin{array}{l}\text { Added to the } \\
\text { nematode's } \\
\text { growth medium }\end{array}$ & $\begin{array}{l}\text { Nematode } \\
\text { (Caenorhabditis } \\
\text { elegans) }\end{array}$ & $\begin{array}{l}\downarrow \text { intestinal calcium levels } \\
\uparrow \text { glutathione S-transferase } 4 \\
\text { enzyme expression }\end{array}$ \\
\hline $\begin{array}{l}\text { Wang et al., } \\
\text { Chemosphere } \\
2019 \text { [75] }\end{array}$ & $\begin{array}{l}\text { Polystyrene } \\
10 \mu \mathrm{m}\end{array}$ & 10 particles $/ \mathrm{mL}$ & 14 days & Culture medium & $\begin{array}{l}\text { Zooplankton } \\
\text { (Artemia } \\
\text { parthenogenetica) } \\
\text { larvae }\end{array}$ & $\begin{array}{l}\text { Histological deformation and } \\
\text { destructuring of the intestinal } \\
\text { epithelium }\end{array}$ \\
\hline $\begin{array}{l}\text { Paul-Pont et al., } \\
\text { Environmental } \\
\text { Pollution } \\
2016[76]\end{array}$ & $\begin{array}{l}\text { Polystyrene } \\
\text { microbeads } \\
(2 \text { and } 6 \mu \mathrm{m})\end{array}$ & $32 \mu \mathrm{g} / \mathrm{L}$ & 7 days & $\begin{array}{l}\text { Supplied with } \\
\text { Chaetoceros } \\
\text { mueller algae as } \\
\text { a food source }\end{array}$ & $\begin{array}{l}\text { Mussel } \\
\text { (Mytiulus spp) }\end{array}$ & $\begin{array}{l}\text { In digestive gland } \\
\downarrow \text { catalase activity } \\
\downarrow \text { glutathione reductase activity } \\
\downarrow \text { lipid peroxidation }\end{array}$ \\
\hline $\begin{array}{l}\text { Brandts et al., } \\
\text { Sci Total Environ } \\
2018[77]\end{array}$ & $\begin{array}{l}\text { Polystyrene } \\
110 \mathrm{~nm}\end{array}$ & 0.05 to $50 \mathrm{mg} / \mathrm{L}$ & $96 \mathrm{~h}$ & Tank water & $\begin{array}{l}\text { Mussel } \\
\text { (Mytiulus } \\
\text { galloprovincialis) }\end{array}$ & $\begin{array}{l}\text { In digestive gland } \\
\uparrow \text { Hsp70 mRNA levels, total oxidant } \\
\text { status, total antioxidant capacity, } \\
\text { and lipid peroxidation }\end{array}$ \\
\hline $\begin{array}{l}\text { Revel et al., } \\
\text { Frontiers in } \\
\text { Environmental } \\
\text { Science } 2019 \text { [78] }\end{array}$ & $\begin{array}{l}\text { Commercial } \\
\text { polyethylene and } \\
\text { polystyrene mixture } \\
(<400 \mu \mathrm{m})\end{array}$ & $\begin{array}{l}0.008,10 \\
100 \mu \mathrm{g} / 1\end{array}$ & 10 days & Tank water & $\begin{array}{l}\text { Mussel } \\
\text { (Mytilus spp.) }\end{array}$ & $\begin{array}{l}\downarrow \text { glutathione } S \text { transferase and } \\
\text { superoxide dismutase activities } \\
\text { (at } 100 \mu \mathrm{g} / \mathrm{L} \text { ) } \\
\uparrow \text { superoxide dismutase and catalase } \\
\text { activities (at } 0.008 \text { and } 10 \mu \mathrm{g} / \mathrm{L} \text { ) }\end{array}$ \\
\hline \multicolumn{7}{|l|}{ Vertebrates } \\
\hline $\begin{array}{l}\text { Asmoniate et al., } \\
\text { Environ. } \\
\text { Sci.Technol. } 2018 \text { [79] }\end{array}$ & $\begin{array}{l}\text { Polystyrene } \\
100-400 \mu \mathrm{m}\end{array}$ & 10 mg /fish/day & 4 weeks & Food & $\begin{array}{l}\text { Rainbow trout } \\
\text { (Oncorhynchus } \\
\text { mykiss) }\end{array}$ & $\begin{array}{l}\text { No variations in paracellular } \\
\text { permeability, } \\
\text { intestinal tight junction and } \\
\text { cytokines mRNA expression, } \\
\text { or ion transport }\end{array}$ \\
\hline $\begin{array}{l}\text { Huang et al., } \\
\text { Sc Total Environ. } \\
2020[80]\end{array}$ & $\begin{array}{l}\text { Polystyrene; } \\
32-40 \\
\mu \mathrm{m}\end{array}$ & $\begin{array}{l}100 \text { and } \\
1000 \mu \mathrm{g} / \mathrm{L}\end{array}$ & 28 days & Tank water & $\begin{array}{l}\text { Juvenile guppy } \\
\text { (Poecilia } \\
\text { reticulata) }\end{array}$ & $\begin{array}{l}\downarrow \text { digestive enzymes activity } \\
\uparrow \text { goblet cells secretion } \\
\uparrow \text { gut secretion of TNFa, IFNy } \\
\text { and IL6 }\end{array}$ \\
\hline $\begin{array}{l}\text { Ahrendt et al., } \\
\text { Mar Pollut Bull } \\
2020[81]\end{array}$ & $\begin{array}{l}\text { Poly(styrene-co- } \\
\text { divinylbenzene) } \\
8 \mu \mathrm{m}\end{array}$ & $\begin{array}{l}0.02 \text { and } \\
0.2 \mathrm{~g} / \mathrm{g} \text { food }\end{array}$ & $\begin{array}{l}\text { Once a day } \\
\text { for } 45 \text { days }\end{array}$ & Diet & $\begin{array}{l}\text { Juvenile } \\
\text { intertidal fish } \\
\text { (Girella laevifrons) }\end{array}$ & $\begin{array}{l}\text { Dose-dependent whole intestine } \\
\text { histological damage: } \\
\text { leukocyte infiltration, hyperemia, } \\
\text { and crypt and villus cell loss }\end{array}$ \\
\hline $\begin{array}{l}\text { Gu et al., } \\
\text { J. Hazard. Mater. } \\
2020[82]\end{array}$ & $\begin{array}{l}\text { Polystyrene } \\
100 \mathrm{~nm}\end{array}$ & $\begin{array}{l}10^{4} \text { and } 10^{6} \\
\text { particles } / L\end{array}$ & 14 days & Tank water & $\begin{array}{l}\text { Juvenile large } \\
\text { yellow } \\
\text { croaker }\end{array}$ & $\begin{array}{l}\downarrow \text { digestive enzymes activity (lipase, } \\
\text { trypsin, and lysozyme) }\end{array}$ \\
\hline $\begin{array}{l}\text { Kang et al., } \\
\text { J Hazard. } \\
\text { Mater. } \\
2020[83]\end{array}$ & $\begin{array}{l}\text { Polystyrene } \\
50 \mathrm{~nm} \text { (NP) } \\
\text { and } 45 \mu \mathrm{m}(\mathrm{MP})\end{array}$ & $2.5 \mu \mathrm{g} / \mathrm{mL}$ & 14 days & $\begin{array}{l}\text { Artificial sea } \\
\text { water }\end{array}$ & $\begin{array}{l}\text { Medaka } \\
\text { (Oryzias. } \\
\text { melastigma) }\end{array}$ & $\begin{array}{l}\uparrow \text { mucus secretion (NP and MP) } \\
\text { No variation of villus length and } \\
\text { width (NP and MP) } \\
\uparrow \text { gut D-lactate levels (MP) } \\
\uparrow \text { gut diamine oxidase levels } \\
\text { (NP and MP) } \\
\text { Gut oxidative stress: } \\
\text { NP: } \downarrow \text { ROS, } \uparrow \text { SOD, } \uparrow \text { CAT, } \uparrow \text { GST } \\
\text { MP: } \uparrow \text { ROS, } \downarrow \text { SOD, } \downarrow \text { CAT, no } \\
\text { variation of GST }\end{array}$ \\
\hline $\begin{array}{l}\text { Jin et al., } \\
\text { Environ. Pollut. } \\
2018[84]\end{array}$ & $\begin{array}{l}\text { Polystyrene } \\
0,5 \text { and } 50 \mu \mathrm{m}\end{array}$ & 1000 mg/L & 14 days & Tank water & $\begin{array}{l}\text { Zebrafish } \\
\text { (Danio rerio) }\end{array}$ & $\begin{array}{l}0.5 \mu \mathrm{m} \text { beads: } \\
\uparrow \text { gut mRNA and protein levels } \\
\text { of IL1a, } \\
\text { IL } 1 \beta \text { and IFN } \\
50 \mu \mathrm{m} \text { beads: no differences }\end{array}$ \\
\hline $\begin{array}{l}\text { Qiao, Sheng, et al., } \\
\text { Sci.Total Environ. } \\
2019 \text { [85] }\end{array}$ & $\begin{array}{l}\text { Polystyrene } \\
5 \mu \mathrm{m}\end{array}$ & $50 \& 500 \mu \mathrm{g} / \mathrm{L}$ & 21 days & Tank water & $\begin{array}{l}\text { Zebrafish } \\
\text { (Danio rerio) }\end{array}$ & $\begin{array}{l}\uparrow \text { catalase and superoxide } \\
\text { dismutase activities } \\
\downarrow \text { gut D-lactate content }\end{array}$ \\
\hline $\begin{array}{l}\text { Gu et al., } \\
\text { Environ. Sci. } \\
\text { Technol. } 2020 \text { [86] }\end{array}$ & $\begin{array}{l}\text { Polystyrene } \\
100 \text { nm, } \\
5 \mu \mathrm{m}, 200 \mu \mathrm{m}\end{array}$ & $500 \mu \mathrm{g} / \mathrm{L}$ & 21 days & Tank water & $\begin{array}{l}\text { Zebrafish } \\
\text { (Danio rerio) }\end{array}$ & $\begin{array}{l}\uparrow \text { intestinal level of TLR2 protein } \\
(100 \mathrm{~nm}, 200 \mu \mathrm{m}) \\
\uparrow \text { mucus secretion (100 nm) } \\
\text { Significant transcriptome variations: } \\
\text { specific of the NP/MP type, and } \\
\text { specific of the intestinal cell } \\
\text { population (enterocytes, secretory }\end{array}$ \\
\hline
\end{tabular}


Table 1 Overview of in vivo studies of the effects of nano- and microplastic exposure on the gut epithelium. *This has been calculated by the authors based on Bachmanov AA et al. Behav Genet 2002 [73] (Continued)

\begin{tabular}{|c|c|c|c|c|c|c|}
\hline Reference & Nano-microplastics & Dosage & $\begin{array}{l}\text { Duration } \\
\text { of exposure }\end{array}$ & $\begin{array}{l}\text { Route of } \\
\text { exposure }\end{array}$ & Species & $\begin{array}{l}\text { Observed effects related to the } \\
\text { gut epithelium }\end{array}$ \\
\hline & & & & & & $\begin{array}{l}\text { cells, M1 and M2 macrophages, T } \\
\text { and B cells) }\end{array}$ \\
\hline $\begin{array}{l}\text { Qiao, Deng, et al., } \\
\text { Chemosphere. } \\
2019 \text { [59] }\end{array}$ & $\begin{array}{l}\text { Polystyrene } \\
\text { Beads } 15 \mu \mathrm{m} \\
\text { Fragments } 4-40 \mu \mathrm{m} \\
\text { Polypropylene } \\
\text { Fibres } 20-200 \mu \mathrm{m}\end{array}$ & $10 \mu \mathrm{g} / \mathrm{L}$ & 21 days & Tank water & $\begin{array}{l}\text { Zebrafish } \\
\text { (Danio rerio) }\end{array}$ & $\begin{array}{l}\downarrow \text { mucus secretion (fibres) } \\
\uparrow \text { superoxide dismutase activity } \\
\downarrow D \text {-lactate levels } \\
\uparrow \| 1 \text { la levels (fragments and fibres) }\end{array}$ \\
\hline $\begin{array}{l}\text { Peda et al., } \\
\text { Environ Pollut } \\
2016[87]\end{array}$ & $\begin{array}{l}\text { Polyvinyl } \\
\text { chloride } \\
<0.3 \mathrm{~mm}\end{array}$ & $\begin{array}{l}1 \% \mathrm{w} / \mathrm{w} \\
\text { in food }\end{array}$ & 90 days & Food & $\begin{array}{l}\text { European sea } \\
\text { bass } \\
\text { (Dicentrarchus } \\
\text { labrax L) }\end{array}$ & $\begin{array}{l}\text { Histopathological alterations in } \\
\text { the distal intestine } \\
\text { (edema, villus desquamation, } \\
\text { detached epithelium, and loss } \\
\text { of epithelial structure) }\end{array}$ \\
\hline $\begin{array}{l}\text { Espinosa et al., Fish } \\
\text { Shellfish Immunol. } \\
2017 \text { [88] }\end{array}$ & $\begin{array}{l}\text { Polyvinyl chloride } \\
\text { Polyethylene } \\
40-150 \mu \mathrm{m}\end{array}$ & $\begin{array}{l}100 \text { and } \\
500 \mathrm{mg} / \mathrm{kg} \\
\text { of diet }\end{array}$ & 3 weeks & Food & $\begin{array}{l}\text { Gilthead } \\
\text { seabream } \\
\text { (Sparus aurata) }\end{array}$ & $\begin{array}{l}\text { PVC } 500 \mathrm{mg} / \mathrm{kg} \text { : } \\
\uparrow \text { goblet cells count, villus thickness, } \\
\text { and expression of intestinal } \\
\text { nuclear factor } \\
\text { E2-related factor } 2 \mathrm{Nrf2} \\
\text { PE } 100 \text { and } 500 \mathrm{mg} / \mathrm{kg} \text { : } \\
\downarrow \text { goblet cell count and villus height }\end{array}$ \\
\hline $\begin{array}{l}\text { Jabeen et al., } \\
\text { Chemosphere } \\
2018 \text { [89] }\end{array}$ & $\begin{array}{l}\text { Ethylene vinyl acetate } \\
0.7-5 \mathrm{~mm} \text { fibres }\end{array}$ & $\begin{array}{l}55-76 \text { fibres per } \\
\text { fish/day }\end{array}$ & $\begin{array}{l}3 \text { days a } \\
\text { week for } 6 \\
\text { weeks }\end{array}$ & Food & $\begin{array}{l}\text { Goldfish } \\
\text { (Carassius } \\
\text { auratus) }\end{array}$ & $\begin{array}{l}\text { Histologically documented inflammatory } \\
\text { infiltration and breakage of epithelium } \\
\text { in the proximal and distal intestine }\end{array}$ \\
\hline $\begin{array}{l}\text { Limonta et al., } \\
\text { Sci rep } \\
2019[90]\end{array}$ & $\begin{array}{l}\text { Irregularly shaped high density } \\
\text { polyethylene and polystyrene } \\
\text { particles }\end{array}$ & $\begin{array}{l}100 \text { and } \\
1000 \mu \mathrm{g} / \mathrm{L}\end{array}$ & 20 days & Food & $\begin{array}{l}\text { Zebrafish } \\
\text { (Danio rerio) }\end{array}$ & $\begin{array}{l}\text { In the intestinal epithelium: } \\
\text { epithelial detachment, } \\
\uparrow \text { neutrophils count } \\
\downarrow \text { goblet cell count }\end{array}$ \\
\hline $\begin{array}{l}\text { Lu et al., } \\
\text { Sci.Total Environ. } \\
2018 \text { [91] }\end{array}$ & $\begin{array}{l}\text { Polystyrene } \\
0.5 \text { and } 50 \mu \mathrm{m}\end{array}$ & $\begin{array}{l}100 \text { and } \\
1000 \mu \mathrm{g} / \mathrm{L} \\
\sim 26 \text { and } \\
266 \mu \mathrm{g} / \mathrm{kg} \mathrm{bw/} \\
\text { day* }^{*}\end{array}$ & 5 weeks & Drinking water & $\begin{array}{l}\text { ICR mice } \\
\text { (Mus musculus) }\end{array}$ & $\begin{array}{l}\downarrow \text { mucus secretion } \\
\downarrow \text { Muc1 transcript levels } \\
\downarrow \text { Klf4 transcript levels }(1000 \mu \mathrm{g} / \mathrm{L} \text { only) }\end{array}$ \\
\hline $\begin{array}{l}\text { Jin et al., } \\
\text { Sci.Total Environ. } \\
2019[60]\end{array}$ & $\begin{array}{l}\text { Polystyrene } \\
5 \mu \mathrm{m}\end{array}$ & $\begin{array}{l}100 \text { and } \\
1000 \mu \mathrm{g} / \mathrm{L} \\
\sim 26 \text { and } \\
266 \mu \mathrm{g} / \mathrm{kg} \mathrm{bw/} \\
\text { day* }^{*}\end{array}$ & 6 weeks & Drinking water & $\begin{array}{l}\text { ICR mice } \\
\text { (Mus musculus) }\end{array}$ & $\begin{array}{l}\downarrow \text { Mucl and Klf4 transcript levels } \\
\downarrow \text { Cftr, Nkccl and Nhe3 transcription in } \\
\text { the colon } \\
\downarrow \text { Anol, Cftr, Slc26a6, Nkccland Nhe3 } \\
\text { transcription in the ileum }\end{array}$ \\
\hline $\begin{array}{l}\text { Stock et am. Arch } \\
\text { Toxicol } \\
2019[92]\end{array}$ & $\begin{array}{l}\text { Polystyrene } \\
1,4,10 \mu \mathrm{m}\end{array}$ & $\begin{array}{l}1.25 \\
25 \text { and } 34 \mathrm{mg} / \mathrm{kg} \\
\text { bw }\end{array}$ & 28 days & Oral gavage & $\begin{array}{l}\text { C57BL/6NTac } \\
\text { mice } \\
\text { (Mus musculus) }\end{array}$ & $\begin{array}{l}\text { Absence of histologically } \\
\text { detectable lesions } \\
\text { or inflammatory responses. }\end{array}$ \\
\hline $\begin{array}{l}\text { Li et al., } \\
\text { Chemosphere. } \\
2020 \text { [93] }\end{array}$ & $\begin{array}{l}\text { Polyethylene } \\
10-150 \mu \mathrm{m}\end{array}$ & $\begin{array}{l}2-20-200 \mu \mathrm{g} / \mathrm{g} \\
\text { Food } \\
\sim 0.0004,0.004 \\
\text { and } 0.04 \mu \mathrm{g} / \mathrm{kg} \\
\text { bw/day* }\end{array}$ & 5 weeks & Food & $\begin{array}{l}\text { C57BL/6 mice } \\
\text { (Mus musculus) }\end{array}$ & $\begin{array}{l}\text { In both colon and duodenum } \\
(200 \mu \mathrm{g} / \mathrm{g} \text { only) } \\
\uparrow \text { histological score } \\
\uparrow \mathrm{TLR} 4, \mathrm{AP}-1 \text { and IRF5 protein expression }\end{array}$ \\
\hline $\begin{array}{l}\text { Deng et al., } \\
\text { Environment } \\
\text { International } \\
2020 \text { [94] }\end{array}$ & $\begin{array}{l}\text { Polyethylene } \\
45-53 \mu \mathrm{m}\end{array}$ & $\begin{array}{l}100 \mathrm{mg} / \mathrm{kg} / \text { day } \\
5.2510^{4} \text { particles/ } \\
\text { day }\end{array}$ & 30 days & Gavage & $\begin{array}{l}\text { CD-1 mice } \\
\text { (Mus musculus) }\end{array}$ & $\begin{array}{l}\uparrow \text { serum D-Lactate levels } \\
\text { No variation serum diamine oxidase } \\
\text { activity } \\
\downarrow \text { gut transcript levels of Cyp 1a2, } \\
\text { Cyp 1a5, H2BMb2, H2Eb1, Aldh8a1, Scarb1 } \\
\uparrow \text { gut transcript levels of Rdh16, Gm8909 }\end{array}$ \\
\hline
\end{tabular}

associated with increased number of pathogenic intestinal bacteria.

The influence of the microplastic's shapes on their gut toxicity has been analyzed in the zebrafish [59]. Exposure to PS beads, PS fragments or PP fibres $(10 \mu \mathrm{g} / \mathrm{L}$, for 21 days) decreased intestinal D-lactate levels. Microplastic fibres also induced a steep decline in the volume of mucus in the gut. Microplastic fibres and fragments caused intestinal inflammation, as characterized by the significant increase in the level of Il1 $\alpha$ in the gut. Microplastic fragments, fibres, and beads also enhanced the activity of superoxide dismutase [59]. Hence, a growing body of evidence suggests that PS can induce oxidative stress and epithelial disruption in the intestine of aquatic species.

The effects of other types or shapes of microplastic have been also assessed in aquatic vertebrates. In the European sea bass Dicentrarchus labrax L, exposure to PVC $(<0.3 \mathrm{~mm}, 1 \% \mathrm{w} / \mathrm{w}$ in food $)$ for 90 days induced histological alterations in the intestine (mainly in the distal part) [87], and contamination of the diet with $500 \mathrm{mg} / \mathrm{kg}$ PVC for three weeks (40 to $150 \mu \mathrm{m}$ ) 
increased the goblet cells number, the villus thickness, and expression of intestinal nuclear factor E2-related factor $2 \mathrm{Nrf2}$. Contamination with $\mathrm{PE}$ at the same dosage and a lower one $(100 \mathrm{mg} / \mathrm{kg})$ decreased the goblet cell number and the villus height [88]. In the goldfish Carassius auratus, oral exposure to ethylene vinyl acetate fibres $(0.7-5 \mathrm{~mm}$ fibres, $55-76$ fibres per fish per day, three days a week for 6 weeks) induced histologically confirmed inflammatory infiltration and breakage of epithelium in the proximal and distal intestine [89]. Epithelial detachment, an increase in the neutrophil count, and a decrease in the goblet cell count were observed in the intestine of zebrafish exposed for 20 days to irregularly shaped high-density PE and PS particles (100 and $1000 \mu \mathrm{g} / \mathrm{L})$ [90].

Furthermore, evidence of the microplastics' intestinal toxicity is now emerging in mammals. Three studies of the effects of PS have been conducted in the mouse. Exposure to microspheres $(0.5$ and $50 \mu \mathrm{m}$ in diameter, 100 and $1000 \mu \mathrm{g} / \mathrm{L}$, for 5 weeks) decreased the mucus secretion and the transcript levels of a major gene related to mucin expression, mucin 1 (Muc1) in colon [91]. Similarly, exposure of mice to PS microspheres microplastics ( $5 \mu \mathrm{m}, 100$ and $1000 \mu \mathrm{g} / \mathrm{L}$, for 6 weeks) significantly decreased the secretion of mucus and the transcript levels of two genes related to mucus secretion, Mucin1 (Muc1) and Kruppel like factor 4 (Klf4) in the gut. After exposure to $1000 \mu \mathrm{g} / \mathrm{L}$ PS microspheres, there was significant down-regulation of the genes related to ion transport, such as cystic fibrosis transmembrane conductance regulator (Cftr), $\mathrm{Na}-\mathrm{K}-2 \mathrm{Cl}$ cotransporter 1 (Nkcc1) and $\mathrm{Na}+$ / $\mathrm{H}+$ exchanger 3 (Nhe3) in the colon, and anoctamin 1 (Ano1), Cftr, solute carrier family 26 member 6 (Slc26a6), Nkccland Nhe3 in the ileum [60]. In contrast, no evidence of inflammation (from the duodenum to the colon) was found in another study of mice exposed to PS microplastics $(1,4$ and $10 \mu \mathrm{m}, 1.25,25$ and $34 \mathrm{mg} / \mathrm{kg}$ bodyweight by oral gavage, three times per week for 28 days); however, the mouse had a different genetic background, the exposure schedule differed, and a much higher dosage was used [92].

Two last studies in the mouse assessed the effects of another type of microplastic: mice were exposed to different amounts of polyethylene microplastics (10$150 \mu \mathrm{m}, 2,20,200 \mu \mathrm{g} / \mathrm{g}$ of food, for 5 weeks). The mice showed clear signs of histological inflammation in the colon and duodenum, and expressed higher protein levels of the innate immune receptor toll-like receptor 4 (TLR4), the proinflammatory transcription factor activator protein 1 AP-1 (also known as c-Jun) and interferon regulatory factor 5 (IRF5) [93]. Another study of exposure of mice to polyethylene microplastiques $(45-53 \mu \mathrm{m}$, $100 \mathrm{mg} / \mathrm{kg} /$ day by gavage, for 30 days) revealed impairments of intestinal permeability (increase of serum D-
Lactate levels) and gene expression (decrease of gut transcript levels of Cyp1a2 (cytochrome P450, family 1, subfamily a, polypeptide 2), Cyp1a5 (cytochrome P450, family 1 , subfamily a, polypeptide, $H 2-D M b 2$ (histocompatibility 2, class II, locus Mb2), H2-Eb1 (histocompatibility 2, class II antigen E beta), Aldh8a1 (aldehyde dehydrogenase 8 family, member A1), Scarb1 (scavenger receptor class $B$, member 1 ) and increase of gut transcript levels of Rdh16 (retinol dehydrogenase 16), Gm8909) [94].

\section{Effects of NANO- and MICROPLASTIC exposure on the gut MICROBIOTA}

The variations in the intestinal microbiota following in vivo exposure to microplastics have been investigated in several contexts. In the sea bass, an analysis of the gut microflora's composition (using denaturing gradient gel electrophoresis fingerprinting) failed to detect shifts in the composition of the bacterial community after 90 days of exposure to native and weathered PVC [95]. In the shrimp, the size, granularity, and viability of gut microbial cells were greater in a group exposed for 7 days to PS nanoparticles $(44 \mathrm{~nm}, 50 \mu \mathrm{g} / \mathrm{mL}$ of tank seawater) than in a control group. The cell viability of the gut microbiota was still increased after 2 and 3 weeks of exposure [96].

Other studies have used metagenomic techniques to explore changes in the gut microbiota (Table 2). In the common springtail Folsomia candida exposed to PVC microspheres ( 80 to $250 \mu \mathrm{m}, 1 \mu \mathrm{g} / \mathrm{kg}$ dry soil for 56 days), the gut microbial diversity was significantly higher and its composition differed significantly, with fewer Bacteroidetes and more Firmicutes [97]. Exposure of Folsomia candida to PE $(<500 \mu \mathrm{m}$, at concentrations of $0.5 \%$ dry weight in the soil, for 28 days), significantly altered the microbial communities and decreased bacterial diversity in the springtail gut [98]. In the crab Eriocheir sinensis, 21 days of exposure to PS microspheres $(5 \mu \mathrm{m}, 40 \mathrm{mg} / \mathrm{L})$ decreased the relative abundance of the Firmicutes and Bacteroidetes, and increased the relative abundance of the Fusobacteria and Proteobacteria [99].

In the juvenile guppy, exposure to PS microspheres $(32-40 \mu \mathrm{m}, 100$ and $1000 \mu \mathrm{g} / \mathrm{L}$, for 28 days) induced dysbiosis, with a greater relative abundance of Proteobacteria and a lower relative abundance of Actinobacteria [80]. In larval zebrafish, exposure to PS microplastics ( 5 and $50 \mu \mathrm{m}, 1000 \mu \mathrm{g} / \mathrm{L}$, for 7 days) induced a decrease in gut microbiota richness and produced significant variations in the genus-level abundance [100]. In the large yellow croaker fish, 14 days of exposure to PS nanoplastics $(100 \mathrm{~nm}, 5.5 \times$ $10^{-12} \mathrm{mg} / \mathrm{L}$ ) enhanced the relative abundance of the Firmicutes and the Bacteroidetes, and diminished the 
Table 2 Overview of in vivo studies of the effects of nano- and microplastic exposure on the gut microbiota (metagenomic analyses). *This has been calculated by the authors based on Bachmanov AA et al. Behav Genet 2002 [73]

\begin{tabular}{|c|c|c|c|c|c|c|c|c|}
\hline Reference & $\begin{array}{l}\text { Nano-micro } \\
\text { plastics }\end{array}$ & Dosage & $\begin{array}{l}\text { Duration } \\
\text { of } \\
\text { exposure }\end{array}$ & $\begin{array}{l}\text { Route of } \\
\text { exposure }\end{array}$ & Species & $\begin{array}{l}\text { Effects on } \\
\text { bacterial diversity }\end{array}$ & $\begin{array}{l}\text { Effects on } \\
\text { bacterial phyla } \\
\text { composition }\end{array}$ & $\begin{array}{l}\text { Effects on bacterial } \\
\text { genera composition }\end{array}$ \\
\hline \multicolumn{9}{|l|}{ Invertebrates } \\
\hline $\begin{array}{l}\text { Zhu et al., } \\
\text { Soil Biology } \\
\text { and } \\
\text { Biochemistry } \\
2018 \text { [97] }\end{array}$ & $\begin{array}{l}\text { Polyvinyl } \\
\text { chloride } \\
\text { particles } 80 \\
\text { to } 250 \mu \mathrm{m}\end{array}$ & $\begin{array}{l}1 \mu \mathrm{gg} / \mathrm{kg} \\
\text { dry soil }\end{array}$ & 56 days & Soil & $\begin{array}{l}\text { Springtail } \\
\text { (Folsomia } \\
\text { candida) }\end{array}$ & $\begin{array}{l}\text { Alpha diversity } \uparrow \\
(p<0.01)\end{array}$ & $\begin{array}{l}\downarrow \text { Bacteroidetes } \\
\uparrow \text { Firmicutes }\end{array}$ & (Family level: $\uparrow$ Bacillaceae) \\
\hline $\begin{array}{l}\text { Ju et al., } \\
\text { Environ. } \\
\text { Pollut. } \\
2019 \text { [98] }\end{array}$ & $\begin{array}{l}\text { Polyethylene } \\
<500 \mu \mathrm{m}\end{array}$ & $\begin{array}{l}0.5 \% \text { dry } \\
\text { weight } \\
\text { in soil }\end{array}$ & 28 days & Soil & $\begin{array}{l}\text { Springtail, } \\
\text { (Folsomia } \\
\text { candida) }\end{array}$ & $\begin{array}{l}\text { Chao1 diversity } \\
\text { index } \downarrow \\
\text { Phylogenetic } \\
\text { diversity } \\
\text { whole-tree index } \downarrow\end{array}$ & No data & $\begin{array}{l}\downarrow \text { Wolbachia } \\
\uparrow \text { Bradyrhizobiaceae, } \\
\text { Ensifer and } \\
\text { Stenotrophomonas }\end{array}$ \\
\hline $\begin{array}{l}\text { Liu et al., } \\
\text { Sci.Total } \\
\text { Environ. } \\
2019 \text { [99] }\end{array}$ & $\begin{array}{l}\text { Polystyrene } \\
5 \mu \mathrm{m}\end{array}$ & $\begin{array}{l}40 \\
\mathrm{mg} / \mathrm{L}\end{array}$ & 21 days & $\begin{array}{l}\text { Tank } \\
\text { water }\end{array}$ & $\begin{array}{l}\text { Crab } \\
\text { (Eriocheir } \\
\text { sinensis) }\end{array}$ & $\begin{array}{l}\text { Shannon diversity } \\
\text { index: } \downarrow\end{array}$ & $\begin{array}{l}\uparrow \text { Cyanobacteria, } \\
\text { Chloroflexi, } \\
\text { Fusobacteria and } \\
\text { Proteobacteria } \\
\downarrow \text { Nitrospirae, } \\
\text { Firmicutes, } \\
\text { and Bacteroidetes }\end{array}$ & 25 significantly different \\
\hline \multicolumn{9}{|l|}{ Vertebrates } \\
\hline $\begin{array}{l}\text { Huang et al., } \\
\text { Sc Total } \\
\text { Environ. } \\
2020[80]\end{array}$ & $\begin{array}{l}\text { Polystyrene; } \\
32-40 \\
\mu \mathrm{m}\end{array}$ & $\begin{array}{l}100 \text { and } \\
1000 \mu \mathrm{g} / \\
\mathrm{L}\end{array}$ & 28 days & $\begin{array}{l}\text { Tank } \\
\text { water }\end{array}$ & $\begin{array}{l}\text { Juvenile } \\
\text { guppy } \\
\text { (Poecilia } \\
\text { reticulata) }\end{array}$ & $\begin{array}{l}\text { Shannon diversity } \\
\text { index: } \downarrow \\
\text { Simpson diversity } \\
\text { index } \uparrow\end{array}$ & $\begin{array}{l}\uparrow \text { Proteobacteria } \\
\downarrow \text { Actinobacteria }\end{array}$ & $\begin{array}{l}\uparrow \text { Gemmobacter and } \\
\text { Rhodobacter }\end{array}$ \\
\hline $\begin{array}{l}\text { Wan et al., } \\
\text { Chemosphere } \\
2019[100]\end{array}$ & $\begin{array}{l}\text { Polystyrene } \\
5 \text { and } 50 \mu \mathrm{m}\end{array}$ & $\begin{array}{l}1000 \mu \mathrm{g} / \\
\mathrm{L}\end{array}$ & 7 days & $\begin{array}{l}\text { Tank } \\
\text { water }\end{array}$ & $\begin{array}{l}\text { Larval } \\
\text { zebrafish } \\
\text { (Danio rerio) }\end{array}$ & $\begin{array}{l}\text { Chao1 diversity } \\
\text { index: } \downarrow(5 \mu \mathrm{m})\end{array}$ & $\begin{array}{l}\text { No significant } \\
\text { variation }\end{array}$ & $\begin{array}{l}5 \mu \mathrm{m}: \downarrow \text { Sphaerotilus, } \\
\text { Haliangium and Leptothrix } \\
\uparrow \text { Methyloversatilis, } \\
\text { Polynucleobacter, } \\
\text { Legionella and Ottowia } \\
50 \mu \mathrm{m}: \downarrow \text { Pseudomonas } \\
\uparrow \text { Flectobacillus and } \\
\text { Methylophilus } \\
5 \text { and } 50 \mu \mathrm{m}: \downarrow \\
\text { Methylobacterium }\end{array}$ \\
\hline $\begin{array}{l}\text { Gu et al., } \\
\text { J. Hazard. } \\
\text { Mater. } \\
2020[82]\end{array}$ & $\begin{array}{l}\text { Polystyrene } \\
100 \mathrm{~nm}\end{array}$ & $\begin{array}{l}5.5 \times \\
10^{-12} \\
\mathrm{mg} / \mathrm{L}\end{array}$ & 14 days & $\begin{array}{l}\text { Tank } \\
\text { water }\end{array}$ & $\begin{array}{l}\text { Large yellow } \\
\text { Croaker } \\
\text { (Larimichthys } \\
\text { croceus) }\end{array}$ & $\begin{array}{l}\text { Chao } 1 \text { diversity } \\
\text { index } \downarrow \\
\text { No variation of } \\
\text { Shannon } \\
\text { diversity index }\end{array}$ & $\begin{array}{l}\uparrow \text { Bacteroidetes, } \\
\text { Firmicutes } \\
\downarrow \text { Proteobacteria }\end{array}$ & $\begin{array}{l}\uparrow \text { Lactobacillus, } \\
\text { Parabacteroides, Alistipes }\end{array}$ \\
\hline $\begin{array}{l}\text { Kang et al. } \\
\text { J Hazard. } \\
\text { Mater. } \\
2020 \text { [83] }\end{array}$ & $\begin{array}{l}\text { Polystyrene } \\
\mathbf{5 0} \mathbf{n m}(\mathbf{N P}) \\
\text { and } 45 \mu \mathrm{m} \\
(\mathrm{MP})\end{array}$ & $\begin{array}{l}2.5 \mu \mathrm{g} / \\
\mathrm{mL}\end{array}$ & 14 days & $\begin{array}{l}\text { Artificial } \\
\text { sea water }\end{array}$ & $\begin{array}{l}\text { Medaka } \\
\text { (Oryzias. } \\
\text { melastigma) }\end{array}$ & $\begin{array}{l}\text { Alpha diversity } \uparrow \\
\text { (MP only) }\end{array}$ & $\begin{array}{l}\downarrow \text { Bacteroidetes } \\
\text { (NP and MP), }\end{array}$ & $\begin{array}{l}\text { NP and MP: } \\
\downarrow \text { Vicingus, Shewanella } \\
\uparrow \text { Lewinella, Pseudomonas, } \\
\text { Thalassospira, Parahaliea. }\end{array}$ \\
\hline $\begin{array}{l}\text { Jin et al., } \\
\text { Environ. } \\
\text { Pollut. } \\
2018 \text { [84] }\end{array}$ & $\begin{array}{l}\text { Polystyrene } \\
0,5 \text { and } \\
50 \mu \mathrm{m}\end{array}$ & $\begin{array}{l}1000 \\
\mathrm{mg} / \mathrm{L}\end{array}$ & 14 days & $\begin{array}{l}\text { Tank } \\
\text { water }\end{array}$ & $\begin{array}{l}\text { Zebrafish } \\
\text { (Danio rerio) }\end{array}$ & $\begin{array}{l}\text { Shannon diversity } \\
\text { index: } \uparrow\end{array}$ & $\begin{array}{l}\uparrow \text { Firmicutes, } \\
\downarrow \text {-Proteobacteria }\end{array}$ & 29 significantly different \\
\hline $\begin{array}{l}\text { Qiao, Sheng, } \\
\text { et al., Sci.Total } \\
\text { Environ. } \\
2019 \text { [85] }\end{array}$ & $\begin{array}{l}\text { Polystyrene } \\
5 \mu \mathrm{m}\end{array}$ & $\begin{array}{l}50- \\
500 \mu \mathrm{g} / \mathrm{L}\end{array}$ & 21 days & $\begin{array}{l}\text { Tank } \\
\text { water }\end{array}$ & $\begin{array}{l}\text { Zebrafish } \\
\text { (Danio rerio) }\end{array}$ & $\begin{array}{l}\text { Shannon diversity } \\
\text { index: } \downarrow 17-29 \% \text { in } \\
\text { the } 50 \text { and } 500 \mu \mathrm{g} / \\
\mathrm{L} \text { MP groups } \\
\text { respectively }(p< \\
0.05 \text { ) }\end{array}$ & $\begin{array}{l}\uparrow \text { Fusobacteria } \\
\downarrow \text { Proteobacteria }\end{array}$ & (Family level: $\uparrow 12 \downarrow 13$ ) \\
\hline $\begin{array}{l}\text { Qiao, Deng, } \\
\text { et al., } \\
\text { Chemosphere. } \\
2019 \text { [59] }\end{array}$ & $\begin{array}{l}\text { Polystyrene } \\
\text { fibre } \\
20-100 \mu \mathrm{m}\end{array}$ & $10 \mu \mathrm{g} / \mathrm{L}$ & 21 days & $\begin{array}{l}\text { Tank } \\
\text { water }\end{array}$ & $\begin{array}{l}\text { Zebrafish } \\
\text { (Danio rerio) }\end{array}$ & $\begin{array}{l}\text { Abundance } \\
\text { coverage-based es- } \\
\text { timator: } \uparrow 107.5 \% \text { in } \\
\text { the } \\
\text { fibre-MP group } \\
(p<0.05) \\
\text { Simpson's diversity }\end{array}$ & $\begin{array}{l}\uparrow \text { Proteobacteria, } \\
\downarrow \text { Actinobacteria, }\end{array}$ & $\begin{array}{l}\uparrow \text { Gordonia } \\
\downarrow \text { Aeromonas, } \\
\text { Pseudomonas }\end{array}$ \\
\hline
\end{tabular}


Table 2 Overview of in vivo studies of the effects of nano- and microplastic exposure on the gut microbiota (metagenomic analyses). *This has been calculated by the authors based on Bachmanov AA et al. Behav Genet 2002 [73] (Continued)

\begin{tabular}{|c|c|c|c|c|c|c|c|c|}
\hline Reference & $\begin{array}{l}\text { Nano-micro } \\
\text { plastics }\end{array}$ & Dosage & $\begin{array}{l}\text { Duration } \\
\text { of } \\
\text { exposure }\end{array}$ & $\begin{array}{l}\text { Route of } \\
\text { exposure }\end{array}$ & Species & $\begin{array}{l}\text { Effects on } \\
\text { bacterial diversity }\end{array}$ & $\begin{array}{l}\text { Effects on } \\
\text { bacterial phyla } \\
\text { composition }\end{array}$ & $\begin{array}{l}\text { Effects on bacterial } \\
\text { genera composition }\end{array}$ \\
\hline & & & & & & $\begin{array}{l}\text { index: } \downarrow 45.7 \% \text { in } \\
\text { the fibre-MP } \\
\text { group }(p<0.05)\end{array}$ & & \\
\hline $\begin{array}{l}\text { Jin et al., } \\
\text { Sci.Total } \\
\text { Environ. } \\
2019 \text { [60] }\end{array}$ & $\begin{array}{l}\text { Polystyrene } \\
5 \mu \mathrm{m}\end{array}$ & $\begin{array}{l}1000 \mu \mathrm{g} / \\
\mathrm{L} \\
\sim \\
266 \mu \mathrm{g} / \\
\mathrm{kg} \mathrm{bw/} \\
\mathrm{day}^{*}\end{array}$ & 6 weeks & $\begin{array}{l}\text { Drinking } \\
\text { water }\end{array}$ & $\begin{array}{l}\text { ICR } \\
\text { Mice } \\
\text { (Mus } \\
\text { musculus) }\end{array}$ & $\begin{array}{l}\text { Phylogenetic } \\
\text { diversity } \\
\text { whole-tree index } \\
\downarrow\end{array}$ & $\begin{array}{l}\downarrow \\
a \text {-Proteobactria } \\
\gamma \text {-Proteobacteria }\end{array}$ & $\begin{array}{l}\downarrow \text { Parabacteroides, } \\
\text { Prevotella, } \\
\text { Dehalobacterium, } \\
\text { Turicibacter, } \\
\text { Bifidobacterium, } \\
\text { Phascolarctobacterium, } \\
\text { Lachnospira, Haemophilus, } \\
\text { Adlercreutzia, } \\
\text { Megamonas, Blautia, } \\
\text { Dialister and Veillonella } \\
\uparrow \text { Coprococcus and } \\
\text { Anaeroplasma }\end{array}$ \\
\hline $\begin{array}{l}\text { Lu et al., } \\
\text { Sci.Total } \\
\text { Environ. } \\
2018 \text { [91] }\end{array}$ & $\begin{array}{l}\text { Polystyrene } \\
0.5 \text { and } \\
50 \mu \mathrm{m}\end{array}$ & $\begin{array}{l}1000 \mu \mathrm{g} / \\
\mathrm{L} \\
\sim \\
266 \mu \mathrm{g} / \\
\mathrm{kg} \mathrm{bw/} \\
\text { day* }^{*}\end{array}$ & 5 weeks & $\begin{array}{l}\text { Drinking } \\
\text { water }\end{array}$ & $\begin{array}{l}\text { ICR } \\
\text { Mice } \\
\text { (Mus } \\
\text { musculus) }\end{array}$ & No data & $\begin{array}{l}\downarrow \text { Firmicutes, } \\
\text { a-Proteobacteria, } \\
\text { Actinobacteria }\end{array}$ & $\begin{array}{l}\downarrow \text { Oscillospira and } \\
\text { Anaerostipes } \\
\uparrow \text { Parabacteroides, } \\
\text { Prevotella, } \\
\text { Dehalobacterium, } \\
\text { Ruminococcus, Bilophila, } \\
\text { Bifidobacterium, } \\
\text { Adlercreutzia, Plesiomona, } \\
\text { Halomonas and } \\
\text { Acinetobacter (after both } \\
0.5 \text { and } 50 \text { mm polystyrene } \\
\text { MP exposure) }\end{array}$ \\
\hline $\begin{array}{l}\text { Luo et al., } \\
\text { Environ. Sci. } \\
\text { Technol } \\
2019[101]\end{array}$ & $\begin{array}{l}\text { Pristine } \\
\text { polystyrene } \\
\text { microspheres } \\
5 \mu \mathrm{m}\end{array}$ & $\begin{array}{l}1000 \mu \mathrm{g} / \\
\mathrm{L} \\
\sim \\
266 \mu \mathrm{g} / \\
\mathrm{kg} \mathrm{bw/} \\
\text { day* }^{*}\end{array}$ & $\begin{array}{l}\text { Gestation } \\
\text { and } \\
\text { lactation } \\
6 \text { weeks } \\
\text { (analysis } \\
\text { of dams) }\end{array}$ & $\begin{array}{l}\text { Drinking } \\
\text { water }\end{array}$ & $\begin{array}{l}\text { ICR } \\
\text { Mice } \\
\text { (Mus } \\
\text { musculus) }\end{array}$ & $\begin{array}{l}\text { Shannon diversity } \\
\text { index: no } \\
\text { significant variation }\end{array}$ & $\begin{array}{l}\text { No significant } \\
\text { variation of } \\
\text { Bacteroidetes, } \\
\text { Proteobacteria, } \\
\text { Firmicutes } \\
\uparrow \text { Actinobacteria } \\
\uparrow \\
\text { Epsilonbacteraeota }\end{array}$ & 14 significantly different \\
\hline $\begin{array}{l}\text { Li et al., } \\
\text { Chemosphere. } \\
2020 \text { [93] }\end{array}$ & $\begin{array}{l}\text { Polyethylene } \\
10-150 \mu \mathrm{m}\end{array}$ & $\begin{array}{l}2-20- \\
200 \mu \mathrm{g} / \mathrm{g} \\
\text { feed } \\
\sim \\
0.0004 \text {, } \\
0.004 \\
\text { and } \\
0.04 \mu \mathrm{g} / \\
\mathrm{kg} \mathrm{bw/} \\
\text { day* }\end{array}$ & 5 weeks & Feed & $\begin{array}{l}\text { C57BL/6 } \\
\text { Mice } \\
\text { (Mus } \\
\text { musculus) }\end{array}$ & $\begin{array}{l}\text { Shannon diversity } \\
\text { index: } \uparrow \\
\text { in the } 200 \mu \mathrm{g} / \mathrm{g} \text { MP } \\
(p<0.05)\end{array}$ & $\begin{array}{l}\uparrow \text { Firmicutes (20- } \\
200 \mu \mathrm{\mu g} / \mathrm{g} \text { ), } \\
\uparrow \text { Melainabacteria } \\
\text { (3 dosages) } \\
\downarrow \text { Bacteroidetes } \\
\text { (20-200) }\end{array}$ & $\begin{array}{l}\uparrow \text { Staphylococcus } \\
\downarrow \text { Parabacteroides } \\
\text { (3 dosages) }\end{array}$ \\
\hline $\begin{array}{l}\text { Deng et al., } \\
\text { Environment } \\
\text { International } \\
2020 \text { [94] }\end{array}$ & $\begin{array}{l}\text { Polyethylene } \\
45-53 \mu \mathrm{m}\end{array}$ & $\begin{array}{l}100 \mathrm{mg} / \\
\mathrm{kg} / \mathrm{day} \\
5.2510^{4} \\
\text { particles/ } \\
\text { day }\end{array}$ & 30 days & Gavage & $\begin{array}{l}\text { CD-1 mice } \\
\text { (Mus } \\
\text { musculus) }\end{array}$ & $\begin{array}{l}\text { Shannon diversity } \\
\text { index: no } \\
\text { significant variation }\end{array}$ & $\uparrow$ Actinobacteria & $\begin{array}{l}\uparrow \text { Lactobacillus } \\
\uparrow \text { Adlercreutzia } \\
\uparrow \text { Butyricimonas } \\
\uparrow \text { Parabacteroides }\end{array}$ \\
\hline
\end{tabular}

abundance of the Proteobacteria [82]. In the medaka, exposure to PS particles $(50 \mathrm{~nm}$ and $45 \mu \mathrm{m}, 2.5 \mu \mathrm{g} / \mathrm{mL}$, for 14 days) enhanced the abundance of Bacteroidetes phylum. At the genus level, PS nano- and microparticles decreased the abundance of Vicingus and Shewanella, and increased the abundance of Lewinella, Pseudomonas, Thalassospira, Parahaliea [83]. In the zebrafish, after 14-day exposure to high-dose of PS
( $1000 \mathrm{mg} / \mathrm{L})$, the abundance of $\gamma$-Proteobacteria decreased significantly and the abundance of Firmicutes increased for both microbead size $(0.5$ and $50 \mu \mathrm{m})$ [84]. Another zebrafish study analyzed the effects of lowerdose exposure to PS microspheres $(5 \mu \mathrm{m}, 50$ and $500 \mu \mathrm{g} / \mathrm{L}$, for 21 days); it showed a decrease of bacterial diversity, an increase of the Fusobacteria abundance and a decrease of the Proteobacteria abundance [85]. 
The effects of PS fibres have also been assessed in the zebrafish: 21 days of exposure to $10 \mu \mathrm{g} / \mathrm{L}$ of PS fibres $(20-100 \mu \mathrm{m})$ induced a diminution of bacterial diversity and variations in specific bacterial phyla (an enhancement in the Proteobacteria and a diminution in the Actinobacteria) [59].

Two studies in the mouse found a large number of significant modifications in the bacterial phyla composition after chronic exposure to PS microspheres $(5 \mu \mathrm{m}$, $1000 \mu \mathrm{g} / \mathrm{L}$, for 5 or 6 weeks) $[60,91]$. The relative abundance of the $\alpha$-Proteobacteria phylum was decreased by microplastic exposure in both studies, and the relative abundance of Actinobacteria and Firmicutes phyla were also reduced in the study by $\mathrm{Lu}$ et al. In contrast, the modifications in bacterial composition observed by Luo et al. were different: an increase in the abundance Actinobacteria but no significant variations in the Proteobacteria and Firmicutes. However, it should be noted that although Luo et al. used a very similar exposure protocol ( $5 \mu \mathrm{m}$ PS beads, $1000 \mu \mathrm{g} / \mathrm{L}$, for around 6 weeks), they exposed mice during gestation and lactation [101].

Two studies focused on PE microplastics. Li et al. (2020) observed that mice exposure to PE microplastics $(10-150 \mu \mathrm{m}, 2,20$ and $200 \mu \mathrm{g} / \mathrm{g}$ of food for 5 weeks) induced an increase in the abundance of the Firmicutes and Melainabacteria phyla and the Staphylococcus genus, and a decrease in the abundance of the Bacteroidetes phylum and the Parabacteroides genus [93]. Deng et al. (2020) observed that mice exposure to PE microplastics $(45-53 \mu \mathrm{m}, 100 \mathrm{mg} / \mathrm{kg} /$ day by gavage, for 30 days) increased the abundance of the Actinobacteria phylum and the abundance of Lactobacillus, Adlercreutzia, Butyricimonas and Parabacteroides genera [94].

In conclusion, all the reports aiming to study the intestinal microbiota in microplastic-exposed animals have observed dysbiosis. Even though the precise features of this dysbiosis vary from one context to another, the observed variations in microflora diversity and composition are likely to cause functional impairments of the immune system.

\section{IMMUNOTOXIC effects of ingested NANO- and MICROPLASTICS}

The intestinal immune system interacts constantly with non-pathogenic commensal organisms and innocuous food antigens that must be tolerated immunologically. At the same time, the intestinal immune system must retain the ability to respond rapidly to infectious threats and toxins. This delicate task relies on several mechanisms involving myeloid cells, innate lymphoid cells, and $\mathrm{T}$ cells that reside in the intestinal lamina propria and the draining mesenteric lymph node. These immune cells circuits are critical components of the immune system. Even though the immunotoxicity of plastics has not been studied directly on the intestinal immune system, in vivo evidence of immunotoxicity of nano- and microplastics suggests that immune cells, including those of intestinal immune system, could be target for plasticinduced damage. Indeed, studies conducted mainly in invertebrates (Table 3) but also in vertebrates (Table 4) have demonstrated that their immune system is compromised by exposure to nano- and microplastics.

\section{In vivo immunotoxicity of nano- and microplastics in invertebrates}

Several studies of invertebrates have linked PS exposure to disruption of the immune system. Exposure of cladoceran Daphnia magna to carboxylate-modified PS nanoparticles $(500 \mathrm{~nm}, 85 \mathrm{mg} / \mathrm{L}$, for 1 year) was associated with higher hemocyte counts [102]. In mussel hemolymph, exposure of PS particles $(110 \mathrm{~nm}, 5 \mathrm{mg} / \mathrm{L}$, for $96 \mathrm{~h}$ ) decreased total antioxidant capacity and gave rise to DNA damage [77]. Exposure of mussels to amino-modified PS nanoparticles $(50 \mathrm{~nm}, 10 \mu \mathrm{g} / \mathrm{L})$ induced changes in hemocytes, depending on the duration of exposure. After a $24 \mathrm{~h}$ exposure, the hemocytes presented mitochondrial and lysosomal disturbances [103]. After two $24 \mathrm{~h}$ periods of exposure $72 \mathrm{~h}$ apart, levels of bactericidal activity and immune-related gene transcription were found to be elevated. After $96 \mathrm{~h}$ of exposure, hemolymph phagocytosis, levels of oxidative stress, and the microbiota were modified [104].

Several research groups have explored the effects of PS on the microscale. In mussels, hemocytes mortality and reactive oxygen species production were increased by exposure to PS microbeads ( 2 and $6 \mu \mathrm{m}, 32 \mu \mathrm{g} / \mathrm{L}$, for 7 days) [76]. In crab hemolymph, the hemocyanin content and the levels of activity of several enzymes related to the immune system (acid phosphatase, alkaline phosphatase, lysozyme and phenoloxidase) were significantly modified by PS exposure $(5 \mu \mathrm{m}, 0.04$ to $40 \mathrm{mg} / \mathrm{mL}$, for 7 , 14 or 21 days), although the direction of change (i.e. an increase or a decrease) varied with the duration or dose level of PS exposure [99]. In Mediterranean sea urchin, exposure to PS microbeads $(10 \mu \mathrm{m}$ and $45 \mu \mathrm{m}, 10$ particles $/ \mathrm{mL}$, for $24 \mathrm{~h}$ ) increased the total coelomocyte count and the intracellular levels of reactive oxygen and nitrogen species, indicating a stress-related impact on these circulating immune cells [105]. In the bivalve mollusk Tegillarca granosa, two studies have shown that PS exposure $(500 \mathrm{~nm}$ and $30 \mu \mathrm{m}, 0.29$ and $1 \mathrm{mg} / \mathrm{L}$, during 14 and 4 days, respectively) leads to several disturbances in hemocytes, with notably a decrease in the cell count and in phagocytosis activity, and numerous variations in immune parameters related to oxidative stress, apoptosis, and the inflammatory response $[109,110]$. In both studies, PS nanoparticles caused more damage than PS microparticles did. 
Table 3 Overview of in vivo studies of the immunotoxic effects of nano- and microplastics in invertebrates

\begin{tabular}{llllll}
\hline Reference & $\begin{array}{l}\text { Nano-micro Dosage } \\
\text { plastics }\end{array}$ & $\begin{array}{l}\text { Duration } \\
\text { of } \\
\text { exposure }\end{array}$ & Route of exposure Species & Observed immunotoxic effects \\
\hline
\end{tabular}

\section{Nanoplastics}

Sadler et al., Environ. Pollut. 2019 [102]

polystyrene beads
$500 \mathrm{~nm}$

Brandts et al.,

Sci.Total Environ. 2018 [77]

Auguste et al., Front.Immunol 2020 [103]

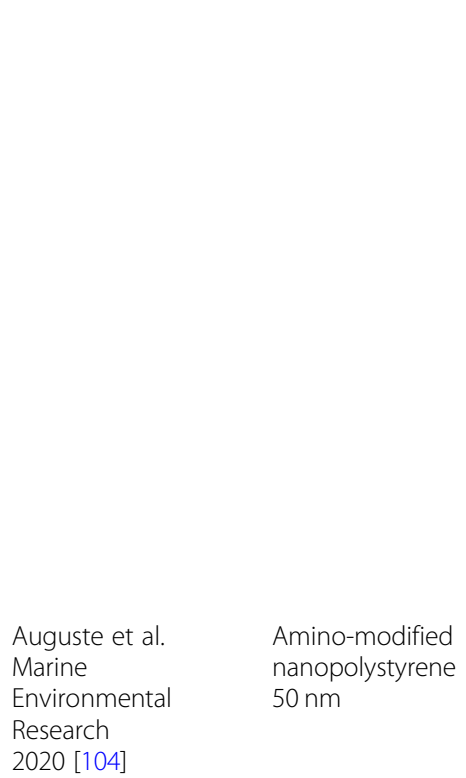

$\begin{array}{ll}\text { Auguste et al. } & \text { Amino-modified } \\ \text { Marine } & \text { nanopolystyrene } \\ \text { Environmental } & 50 \mathrm{~nm} \\ \text { Research } & \\ 2020[104] & \end{array}$

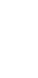

\section{Microplastics}

Paul-Pont et al.,

Environmental

Pollution

2016 [76]

Liu et al.,

Sci. Total Environ

2019 [99]

Polystyrene

$\sim 110 \mathrm{~nm}$

Amino-modified nanopolystyrene $50 \mathrm{~nm}$

\section{$1.25 \pm 0.205$ particles/L, \\ or $85.6 \pm$}

$14.0 \mathrm{mg} / \mathrm{L}$

$0.005-0.05-96 \mathrm{~h}$

$0.5-5-50$

$\mathrm{mg} / \mathrm{L}$

$10 \mu \mathrm{g} / \mathrm{L}$
Tank water

Tank water

Tank water

$\begin{array}{lll}10 \mu \mathrm{g} / \mathrm{L} \quad 96 \mathrm{~h} \quad \text { Tank water } & \text { Mussel } \\ & \text { (Mytilus } & \text { galloprovincialis) }\end{array}$

$\downarrow$ phagocytosis,

Cladoceran $\quad \uparrow$ Hemocyte counts
(Daphnia
magna)

Mussel Hemolymph

(Mytiulus \total antioxidant capacity (5 mg/L)

galloprovincialis) $\uparrow$ DNA damage (all dosages)

$\begin{array}{ll}\text { Mussel } & \text { Hemocytes } \\ \text { (Mytilus. } & O n e \text { exposure: }\end{array}$

galloprovincialis) $\downarrow$ mitochondrial membrane potential (MMP),

$\uparrow$ lysosomal acidification

$\downarrow$ lysosomal membrane stability

$\uparrow$ lysozyme release

No changes in total hemocyte count, subpopulations, phagocytic activity and ROS production

$\downarrow$ transcription of PCNA and p53

No change in hemolymph

bactericidal activity

Two exposures with $72 \mathrm{~h}$ resting period between:

normal hemocyte lysosomal stability, MMP, and lysozyme activity

$\downarrow$ lysosomal membrane destabilization

$\downarrow$ fully mature phagocytes

$\uparrow$ bactericidal activity

$\uparrow$ transcription of immune-related genes

$\downarrow$ NO production.

Hemolymph microbiota composition shift

Polystyrene

$32 \mu \mathrm{g} / \mathrm{L} \quad 7$ days

Supplied with

Chaetoceros mueller

algae as a food

( 2 and $6 \mu \mathrm{m}$ )

Polystyrene

$5 \mu \mathrm{m}$

0.04-0.4-4- 7, 14, and Tank water

$40 \mathrm{mg} / \mathrm{L} \quad 21$

days
Mussel

(Mytilus spp)

$\uparrow$ hemocytes mortality and ROS production

Crab
(Eriocheir
Sinensis)

hemolymph

Hemocyanin content
Immune parameters in the
After 7 days: $\uparrow$ at $0.04 \mathrm{mg} / \mathrm{L}$

After 14 days: $\uparrow$ at 0.04 and $0.4 \mathrm{mg} / \mathrm{L}$

After 21 days: $\downarrow$ at all dosages

Acid phosphatase activity

After 7 days: $\uparrow$ at 4 and $40 \mathrm{mg} / \mathrm{L}$

After 14 days: $\uparrow$ at 0.04 and $0.4 \mathrm{mg} / \mathrm{L}$, $\downarrow 4$ and $40 \mathrm{mg} / \mathrm{L}$

After 21 days: $\uparrow$ at $0.04 \mathrm{mg} / \mathrm{L}, \downarrow 4$ and

$40 \mathrm{mg} / \mathrm{L}$

\section{Alkaline phosphatase activity}

After 7 days: $\uparrow$ at $0.04 \mathrm{mg} / \mathrm{L}, \downarrow 4$ and $40 \mathrm{mg} / \mathrm{L}$

After 14 days: $\uparrow$ at $0.04 \mathrm{mg} / \mathrm{L}$

After 21 days: $\downarrow$ at all dosages

Lysozyme activity

After 7 days: $\downarrow$ at $40 \mathrm{mg} / \mathrm{L}$

After 14 days: $\downarrow$ at 0.4 and $4 \mathrm{mg} / \mathrm{L}$ 
Table 3 Overview of in vivo studies of the immunotoxic effects of nano- and microplastics in invertebrates (Continued)

\begin{tabular}{llllll}
\hline Reference & $\begin{array}{l}\text { Nano-micro Dosage } \\
\text { plastics }\end{array}$ & $\begin{array}{l}\text { Duration Route of exposure } \\
\text { of } \\
\text { exposure }\end{array}$ & Species & Observed immunotoxic effects \\
\hline
\end{tabular}

\begin{tabular}{|c|c|c|c|c|c|c|}
\hline & & & & & & $\begin{array}{l}\text { After } 21 \text { days: } \downarrow \text { at } 4 \text { et } 40 \mathrm{mg} / \mathrm{L} \\
\text { Phenoloxidase activity } \\
\text { After } 7 \text { days: } \uparrow \text { at } 0.04,0.4,4 \mathrm{mg} / \mathrm{L}, \downarrow \\
40 \mathrm{mg} / \mathrm{L} \\
\text { After } 14 \text { days: } \downarrow \text { at } 0.4,4 \text {, and } 40 \mathrm{mg} / \mathrm{L} \\
\text { After } 21 \text { days: } \downarrow \text { at all dosages } \\
\text { Expression of immune-related } \\
\text { genes in the hemocytes } \\
\text { Hemocyanin and lysozyme: dose } \\
\text { dependent } \downarrow \\
\text { Caspase: } \uparrow 0.04 \text { and } 4 \mathrm{mg} / \mathrm{L}, \downarrow \text { at } 40 \\
\text { mg/L } \\
\text { MyD88: } \uparrow \text { at all dosages }\end{array}$ \\
\hline $\begin{array}{l}\text { Murano et al. } \\
\text { Environmental } \\
\text { Pollution } 2020 \text { [105] }\end{array}$ & $\begin{array}{l}\text { Polystyrene } \\
\text { microbeads } \\
(10 \text { and } 45 \mu \mathrm{m})\end{array}$ & $\begin{array}{l}10 \text { particles } \\
/ \mathrm{mL}\end{array}$ & $\begin{array}{l}24 h \\
48 h \\
72 h\end{array}$ & Tank water & $\begin{array}{l}\text { Mediterranean } \\
\text { sea urchin } \\
\text { (Paracentrotus } \\
\text { lividus) }\end{array}$ & $\begin{array}{l}\uparrow \text { total number of immune cells } \\
\uparrow \text { ratio between red and white } \\
\text { amoebocyte } \\
\text { (at } 3 \text { times for } 10 \mu \mathrm{m} \text { beads and only } \\
\text { at } 48 \text { and } 72 \mathrm{~h} \text { for } 45 \mu \mathrm{m} \text { beads) } \\
\uparrow \text { intracellular levels of reactive } \\
\text { oxygen and nitrogen species } \\
\text { (at } 24 \mathrm{~h} \text { only for both } 10 \text { and } 45 \mu \mathrm{m} \\
\text { beads) } \\
\uparrow \text { total antioxidant capacity (at } 72 \mathrm{~h} \\
\text { for } 10 \mu \mathrm{m} \text { beads) }\end{array}$ \\
\hline $\begin{array}{l}\text { Revel et al., Environ } \\
\text { Sci Pollut Res Int. } \\
2020 \text { [106] }\end{array}$ & $\begin{array}{l}\text { Polyethylene and } \\
\text { Polypropylene } \\
0.4-400 \mu \mathrm{m}\end{array}$ & $L^{10-100 \mu g /}$ & 10 days & Soil & $\begin{array}{l}\text { Ragworm } \\
\text { (Hediste } \\
\text { diversicolor) }\end{array}$ & $\begin{array}{l}\text { Coelomocytes } \\
\text { No variation of phagocytosis activity, } \\
\text { phenoloxydase, } \\
\text { and acid phosphatase }\end{array}$ \\
\hline $\begin{array}{l}\text { Revel et al., Mar. } \\
\text { Pollut. Bull. } 2020 \\
\text { [107] }\end{array}$ & $\begin{array}{l}\text { Polyethylene and } \\
\text { Polypropylene } \\
\text { fragments < } \\
400 \mu \mathrm{m}\end{array}$ & $\begin{array}{l}0.008-10- \\
100 \\
\mu g \text { of } \\
\text { particles/L }\end{array}$ & 10 days & Tank water & $\begin{array}{l}\text { Pacific oyster } \\
\text { (Crassostrea } \\
\text { gigas) }\end{array}$ & $\begin{array}{l}\text { Hemolymph } \\
\text { No variation of ROS production, acid } \\
\text { phosphatase activity, } \\
\text { and DNA damage }\end{array}$ \\
\hline $\begin{array}{l}\text { Green et al., Environ. } \\
\text { Pollut. } 2019 \text { [108] }\end{array}$ & $\begin{array}{l}\text { High density } \\
\text { Polyethylene } \\
\text { (HDPE) } \\
0.48-316 \mu \mathrm{m} \\
\text { Polylactic acid } \\
\text { (PLA) } \\
0.6-363 \mu \mathrm{m}\end{array}$ & $\begin{array}{l}\text { HDPE } 845 \\
\text { particles/L } \\
\text { PLA } 1296 \\
\text { particles/L }\end{array}$ & $\begin{array}{l}52 \text { days } \\
2 \text { h/day }\end{array}$ & $\begin{array}{l}\text { MP-dosed microalgae } \\
\text { Isochrysis galbana }\end{array}$ & $\begin{array}{l}\text { Blue mussel } \\
\text { (Mytilus edulis) }\end{array}$ & $\begin{array}{l}\text { Hemolymph proteome } \\
\text { HDPE group } \\
\text { Dysregulation of } 6 \text { protein involved in } \\
\text { immune response } \\
\uparrow \text { three complement C1q domain- } \\
\text { containing (C1qDC) proteins } \\
\text { (FR715598.1; FR715581; HE609753.1), } \\
\text { and fibrinogen-related protein } \\
\text { (OPL33687.1) } \\
\downarrow \text { macrophage migration inhibitory } \\
\text { factor (HE609105.1), } \\
\text { Microfibril-Associated Glyco } 4 \\
\text { (OPL32613.1) } \\
\text { PLA group } \\
\text { dysregulation of } 3 \text { protein involved in } \\
\text { immune response } \\
\uparrow \text { C1Q Domain Containing } 1 \text { Q19 } \\
\text { (FR715598.1) } \\
\text { and Fibrinogen-Related (OPL33687.1) } \\
\downarrow \text { Microfibril-Associated Glyco } 4 \\
\text { (OPL32613.1) }\end{array}$ \\
\hline $\begin{array}{l}\text { Revel et al. Frontiers } \\
\text { in Environmental } \\
\text { Science } 2019 \text { [78] }\end{array}$ & $\begin{array}{l}\text { Commercial } \\
\text { polyethylene and } \\
\text { polystyrene } \\
\text { mixture } \\
(<400 \mu \mathrm{m})\end{array}$ & $\begin{array}{l}0.008,10 \\
100 \mu \mathrm{g} / \mathrm{L}\end{array}$ & 10 days & Tank water & $\begin{array}{l}\text { Mussel } \\
\text { (Mytilus spp.) }\end{array}$ & $\begin{array}{l}\text { Hemolymph } \\
\text { No variation hemocyte count } \\
\uparrow \text { acide phosphatase activity }(0.008 \\
\text { and } 10 \mu \mathrm{g} / \mathrm{L}) \\
\uparrow \text { DNA damage }(10 \text { and } 100 \mu \mathrm{g} / \mathrm{L})\end{array}$ \\
\hline \multicolumn{7}{|c|}{ Both nanoplastics and microplastics } \\
\hline $\begin{array}{l}\text { Shi et al., J. Hazard. } \\
\text { Mater. } 2020 \text { [109] }\end{array}$ & $\begin{array}{l}\text { Polystyrene beads } \\
500 \mathrm{~nm} \text { (NP) and } \\
30 \mu \mathrm{m}(\mathrm{MP})\end{array}$ & $0.29 \mathrm{mg} / \mathrm{L}$ & 14 days & Tank water & $\begin{array}{l}\text { Bivalve mollusk } \\
\text { (Tegillarca } \\
\text { granosa) }\end{array}$ & $\begin{array}{l}\text { Hemocytes } \\
\downarrow \text { total hemocytes count } \\
\downarrow \text { phagocytosis }\end{array}$ \\
\hline
\end{tabular}


Table 3 Overview of in vivo studies of the immunotoxic effects of nano- and microplastics in invertebrates (Continued)

\begin{tabular}{|c|c|c|c|c|c|c|}
\hline Reference & $\begin{array}{l}\text { Nano-micro } \\
\text { plastics }\end{array}$ & Dosage & $\begin{array}{l}\text { Duration } \\
\text { of } \\
\text { exposure }\end{array}$ & Route of exposure & Species & Observed immunotoxic effects \\
\hline & & & & & & $\begin{array}{l}\downarrow \text { viability (NP only) } \\
\uparrow \text { ROS content } \\
\uparrow \text { Caspase } 3 \text { activity } \\
\uparrow \text { malondialdehyde content } \\
\downarrow \text { ATP content (NP only) } \\
\downarrow \text { pyruvate kinase activity } \\
\uparrow \text { GABA content }\end{array}$ \\
\hline $\begin{array}{l}\text { Tang et al., Environ. } \\
\text { Pollut. } 2020 \text { [1 10] }\end{array}$ & $\begin{array}{l}\text { Polystyrene } \\
500 \mathrm{~nm}(\mathrm{NP}) \text { and } \\
30 \mu \mathrm{m} \text { (MP) and }\end{array}$ & $1 \mathrm{mg} / \mathrm{L}$ & 4 days & Tank water & $\begin{array}{l}\text { Bivalve mollusk } \\
\text { (Tegillarca } \\
\text { granosa) }\end{array}$ & $\begin{array}{l}\text { Hemocytes } \\
\downarrow \text { hemocytes count, basophils count, } \\
\text { phagocytosis } \\
\downarrow \text { lysozyme (NP only) } \\
\downarrow \text { TLR4 (NP only), TRAF6, IKKa, NFKB } \\
\text { gene expression } \\
\uparrow \text { Bcl2 (NP only), Caspase 3, } \\
\text { Calmodulin gene expression }\end{array}$ \\
\hline
\end{tabular}

Other microplastics have been studied individually. Polyethylene and PP fragments $(<400 \mu \mathrm{m}, 0.008$ to $100 \mu \mathrm{g} / \mathrm{L}$, for 10 days) did not show significant immune damage in ragworm and oyster [106, 107]. Specific dysregulation of proteins involved in immune response were observed in hemolymph of mussels exposed to PE and polylactic acid microplastics (845 and 1296 particles/L respectively, $2 \mathrm{~h} /$ day, for 52 days) [108].

Lastly, in Mytilus spp, exposure to a mixture of PE and PS microbeads $(<400 \mu \mathrm{m}, 10 \mu \mathrm{g} / \mathrm{L}$, for 10 days $)$ enhanced hemolymph acid phosphatase activity and DNA damage [78].

\section{In vivo immunotoxicity of nano- and microplastics in vertebrates}

Two studies have assessed the in vivo immunotoxicity of nanoplastics in fishes. In vitro neutrophil function assays showed dose-dependent increases in myeloperoxidase activity and neutrophil extracellular trap release in fathead minnows Pimephales promelas exposed to PS nanoparticles $(41 \mathrm{~nm}, 0.025$ to $0.2 \mu \mathrm{g} / \mu \mathrm{L})$ [111]. Acute exposure to PMMA nanoparticles $(45 \mathrm{~nm}, 0.02$ and 0.2 $\mathrm{mg} / \mathrm{L}$, for $96 \mathrm{~h}$ ) diminished the level of oxidative stress in the plasma [112].

Several studies have explored the in vivo toxicity of micro scale plastics. Polycarbonate microplastics (159 $\mathrm{nm}, 0.025$ to $0.2 \mu \mathrm{g} / \mathrm{ml}, 2 \mathrm{~h}$ ) dose-dependently disturbed neutrophil function in fathead minnows [111]. In contrast, no significant immunotoxicity was observed in trout exposed for 4 weeks to PS microbeads (100$400 \mu \mathrm{m}, 10 \mathrm{mg} /$ fish/day) [79]. Exposure to PE microparticles (250 and $500 \mu \mathrm{g} / \mathrm{L}$, for 30 days) impaired the complement system and the levels of activity of immunity-related enzymes in the plasma of carp [113]. Espinosa et al. showed in fishes that exposure to PVC microplastics $(40-150 \mu \mathrm{m}, 1$ to $500 \mathrm{mg} / \mathrm{kg}$, for between $1 \mathrm{~h}$ and 3 weeks) disturbed phagocytic capacity and increased the head-kidney leukocytes' respiratory burst $[88,114,115]$. Polyethylene also enhanced the headkidney leukocytes' respiratory burst in fishes, and dysregulated major immune response proteins in the hemolymph of mussels $[88,115]$. In zebrafish, exposure to high-density PE and PS particles $(100$ and $1000 \mu \mathrm{g} / \mathrm{L}$, for 20 days) decreased the liver transcript levels of 2 immune genes leukotriene B4 receptor (ltb4r) and interferon induced transmembrane protein (ifitm1) [90].

In mice, exposure to PE microplastics $(10-150 \mu \mathrm{m}, 20$ and $200 \mu \mathrm{g} / \mathrm{g}$, for 5 weeks) modified the serum levels of IL1 $\alpha$ and granulocyte colony-stimulating factor G-CSF, decreased the regulatory $\mathrm{T}$ cell count, and increased the proportion of Th17 cells in splenocytes [93]. The crossgenerational effects of PE exposure $(7 \mu \mathrm{m}, 0.125$ to 2 $\mathrm{mg} /$ day/mouse, for 90 days) have been also studied in the mouse: blood neutrophil counts and IgA levels were elevated in dams, and spleen lymphocytes were altered in both dams and offspring [116].

Lastly, Mancia et al. studied the small-spotted catshark (Scyliorhinus canicula) in the Mediterranean Sea: the presence of macroplastics in the gastrointestinal tract was associated with significant upregulation of the expression of $\mathrm{T}$ cell receptors beta and delta (TCR $\beta$ and TCR $\delta$ ) and immunoglobulin $M(\operatorname{IgM})$ in the spleen [117].

The many alterations observed in these studies not only demonstrate that the immune system is altered by plastics but also highlight the need for more immunotoxicity studies of species more closely related to the human.

\section{MICROPLASTICS as carriers of intestinal toxics and pathogens}

Microplastics may contain additives on average $(4 \% \mathrm{w} /$ $\mathrm{w}$, on average) and can adsorb contaminants [63, 118]. Both additives and contaminants can be of organic as 
Table 4 Overview of in vivo studies of the immunotoxic effects of nano- and microplastics in vertebrates. *This has been calculated by the authors based on Bachmanov AA et al. Behav Genet 2002 [73]

\begin{tabular}{llll}
\hline Reference & Nano-microplastics & Dosage & $\begin{array}{l}\text { Duration } \\
\text { of } \\
\text { exposure }\end{array}$
\end{tabular}

\section{Nanoplastics}

Greven et al.,

Environ. Toxicol.

Polystyrene

$41 \mathrm{~nm}$

$0.025-0.05-0.1-0.2 \quad 2 h$

$\mu \mathrm{g} / \mu \mathrm{L}$

Chem. 2016

[111]

$\begin{array}{ll}\text { Brandts et al., } & \text { Polymethylmethacrylate } \\ \text { Genomics. } & \sim 45 \mathrm{~nm} \\ 2018 & \end{array}$

Greven et al, Environ. Toxicol.

Chem. 2016

[111]

\section{Polycarbonate \\ $158.7 \mathrm{~nm}$}

Asmoniate et al.,

Environ.

Sci.Technol.2018

[79]

Banaee et al.,

Chemosphere

2019

[113]
2018

[112]

\section{Microplastics}

\author{
Polystyrene \\ 100-400 $\mu \mathrm{m}$ \\ Isolated from body scrub \\ (likely polyethylene) \\ No data on size
}

$0.02-0.2-2-20 \mathrm{mg} / \quad 96 \mathrm{~h}$

L

0.025-0.05-0.1-0.2 2h

$\mu \mathrm{g} / \mu \mathrm{L}$

250 and $500 \mu \mathrm{g} / \mathrm{L} \quad 30$ days

$$
30 \text { days }
$$

(2)

Espinosa et al., Fish Polyvinyl chloride

Shellfish Immunol.

2017

[114]

Espinosa et al., Environ. Pollut. 2018

[115]

\section{0-150 um}

Polyvinyl chloride - Polyethylene 40-150 um
$100-500 \mathrm{mg} / \mathrm{kg}$

of food

15,

30 days

$1 \mathrm{~h}$

$24 \mathrm{~h}$
Tank water
$10 \mathrm{mg} /$ fish/day 4 weeks Food
Tank

water

Tank

water

Tank

water

Tank

water

minnows

(Pimephales

promelas)

Rainbow trout (Oncorhynchus mykiss)

Common carp (Cyprinus carpio) minnows (Pimephales promelas)

European sea

Dicentrarchus abrax)

\section{Neutrophil function in vitro} assays

Dose dependent

$\uparrow m y e l o p e r o x i d a s e$ activity and neutrophil extracellular trap release

Plasma $\downarrow$ esterase activity (biomarker of oxidative stress) (0.02 and $0.2 \mathrm{mg} / \mathrm{L}$ )

\section{Neutrophil function in vitro} assays

Dose dependent $\uparrow$ myeloperoxidase activity, neutrophil extracellular trap release, and oxidative burst

No variation of immune parameters: serum lysosyme activity blood immune cells counts

Plasma

$\downarrow$ total immunoglobulin $\downarrow$ alternative complement activity

$\downarrow$ complement C3 $\downarrow$ complement C4 $\downarrow$ lysozyme activity $\downarrow$ acetylcholinesterase activity $\downarrow$-glutamyl-transferase activity $\uparrow$ lactate deshydrogenase activity

$a$ alkaline phosphatase activity

$\uparrow$ head-kidney leucocyte phagocytic capacity ( 15 days

seabream (Sparus aurata) only)

European sea bass

(Dicentrarchus Labrax) Gilthead seabream

(Sparus aurata) Gilthead seabream

\section{Head-kidney leucocytes} European sea bass

PVC: $\downarrow$ phagocytic capacity (all dosages, $1 \mathrm{~h}$ and $24 \mathrm{~h}$ )

PE: $\uparrow$ respiratory burst (100 mg/ $\mathrm{mL}, 24 \mathrm{~h}$ )

PVC: $\downarrow$ phagocytic ability, $\uparrow$ respiratory burst $(100 \mathrm{mg} / \mathrm{mL}$, 24h)

PVC and PE: $\uparrow$ Nrf2 expression (100 mg/mL, $1 \mathrm{~h}$ )

Espinosa et al., Fish

Polyvinyl chloride - Polyethylene

$100-500 \mathrm{mg} / \mathrm{kg}$

3 weeks

Food of food
European sea bass

(Dicentrarchus Labrax)

\section{Cellular innate immune} parameters in head kidney leucocytes

PVC: $\uparrow$ phagocytic capacity at both dosages $\uparrow$ respiratory burst activity at $100 \mathrm{mg} / \mathrm{kg}$ $\mathrm{PE}: \uparrow$ respiratory burst activity at both dosages 
Table 4 Overview of in vivo studies of the immunotoxic effects of nano- and microplastics in vertebrates. *This has been calculated by the authors based on Bachmanov AA et al. Behav Genet 2002 [73] (Continued)

\begin{tabular}{|c|c|c|c|c|c|c|}
\hline Reference & Nano-microplastics & Dosage & $\begin{array}{l}\text { Duration } \\
\text { of } \\
\text { exposure }\end{array}$ & $\begin{array}{l}\text { Route of } \\
\text { exposure }\end{array}$ & Species & $\begin{array}{l}\text { Observed immunotoxic } \\
\text { effects }\end{array}$ \\
\hline $\begin{array}{l}\text { Limonta et al., } \\
\text { Sci rep } \\
2019[90]\end{array}$ & $\begin{array}{l}\text { Irregularly shaped high density } \\
\text { polyethylene and polystyrene } \\
\text { particles }\end{array}$ & $\begin{array}{l}100 \text { and } \\
1000 \mu g / L\end{array}$ & 20 days & Food & $\begin{array}{l}\text { Zebrafish } \\
\text { (Danio rerio) }\end{array}$ & $\begin{array}{l}\downarrow \text { liver leukotriene B4 receptor } \\
(\text { (tb } 4 r) \\
\text { and interferon induced } \\
\text { transmembrane protein } 1 \\
\text { (ifitm } 1 \text { ) expression }\end{array}$ \\
\hline $\begin{array}{l}\text { Li et al., } \\
\text { Chemosphere. } \\
2020 \\
{[93]}\end{array}$ & $\begin{array}{l}\text { Polyethylene } \\
10-150 \mu \mathrm{m}\end{array}$ & $\begin{array}{l}2-20-200 \mu \mathrm{g} / \mathrm{g} \\
\sim 0.0004,0.004 \\
\text { and } 0.04 \mu \mathrm{g} / \mathrm{kg} \\
\text { bw/day* }\end{array}$ & 5 weeks & Food & $\begin{array}{l}\text { C57BL/6 } \\
\text { mice } \\
\text { (Mus musculus) }\end{array}$ & 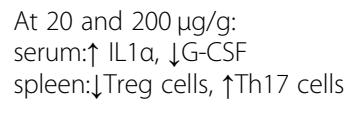 \\
\hline $\begin{array}{l}\text { Park et al., } \\
\text { Toxicology Letters } \\
2020 \\
{[116]}\end{array}$ & $\begin{array}{l}\text { Polyethylene } \\
\text { irregular } \\
\text { micropsheres } \\
16.9 \pm 1.9 \mu \mathrm{m}\end{array}$ & $\begin{array}{l}0.125,0.5 \\
\text { and } 2 \mathrm{mg} / \text { day/ } \\
\text { mouse } \\
\sim 5,20 \text { an } 80 \mu \mathrm{g} / \\
\mathrm{kg} \text { bw/day* }\end{array}$ & 90 days & Gavage & $\begin{array}{l}\text { ICR mice } \\
\text { (Mus musculus) }\end{array}$ & $\begin{array}{l}\text { In dams: } \\
\uparrow \text { blood neutrophils } \\
\uparrow \text { blood lgA levels } \\
\text { In dams and offspring: } \\
\text { alteration of spleen } \\
\text { lymphocytes }\end{array}$ \\
\hline
\end{tabular}

well of inorganic nature. The main plastic additives and adsorbed contaminants for which data are available are the phthalates, bisphenol A, polybrominated diphenyl ethers, polycyclic aromatic hydrocarbons (PAHs) and polychlorinated biphenyls (PCBs). Concentrations of up to $2750 \mathrm{ng} / \mathrm{g}$ of PCB [119] and $24,000 \mathrm{ng} / \mathrm{g}$ of PAHs [120] have been found in microplastics deposited on beaches.

The presence of additives and contaminants in microplastics raises concerns about the latter's ability to accentuate the bioaccumulation of some of them which could be intestinal toxics. Indeed, the bioaccumulation of oxytetracycline and florfenicol, two frequently detected veterinary antibiotics, in edible bivalves (clams) was found to be aggravated by coexposure to microplastics (PS particles, $500 \mathrm{~nm}, 0.26$ $\mathrm{mg} / \mathrm{L})$ [121]. It has been shown that microplastics carry several known intestinal toxics, such as polybrominated diphenyl ethers [122], cadmium [113, 123] and triclosan [124]. In mice, microplastics adsorb phthalate esters and can transport them into the gut, where they accumulate [94].

Secondly, the presence of additives and contaminants in or on microplastics raises concerns about the possible accentuation of the pollutants' toxicity. Indeed, microplastics aggravated the immunotoxicity of bisphenol A and petroleum hydrocarbons in blood clams [125, 126], and the immunotoxicity of cadmium in fish [113]. Polyethylene microplastics increased the toxicity of the pesticide chlorpyrifos in the marine copepod Acartia tonsa [127]. In mice, gut inflammation induced by exposure to organophosphorus flame retardants was aggravated by PE or PS co-exposure $(0.5-1 \mu \mathrm{m}$ beads, $2 \mathrm{mg} / \mathrm{L}$ of drinking water, for 90 days) [61]. Exposure of mice to di (2ethylhexyl) phthalate

(DEHP)-contaminated microplastics for 30 days worsened histological signs of intestinal inflammation, and impairments in intestinal permeability (as revealed by the serum D-lactate level and serum diamine oxidase activity) [94]. Although few data on the intestine per se are available, the above-cited studies demonstrate that microplastics can add to or synergize the adverse effects of the toxics that they contain or have absorbed.

Furthermore, microplastics house distinct communities of microbes, that can form fully developed surface biofilms [128, 129]. Plastic debris supports the growth of specific bacterial consortia, including bacterial pathogens. For example, Vibrio spp. and Escherichia coli have been repeatedly found in microplastic biofilms [128]. These biofilms differ in their microbial composition, relative to biofilms formed on natural substrates [130]. For example, recent analyses of biofilms on microplastics and on two natural substrates (rock and leaf) led to the detection of two opportunistic human pathogens (Pseudomonas monteilii and Pseudomonas mendocina) in the microplastic biofilm only [130]. Therefore, microplastics may serve as vectors for pathogens. Furthermore, the complex microbial consortia in microplastic biofilms may promote horizontal gene transfer between phylogenetically distinct microbes more rapidly than in free-living microbes. Hence, microplastics could also serve as 'hotspots' for the development and dissemination of various drug-resistant human pathogens via coselection mechanisms [131, 132]. In accordance with this concept, it has been shown in mussels that the gut dysbiosis observed after exposure to PE microplastics is associated with an increase of the relative abundance of some potential human pathogens [133]. Exposure to microplastic biofilms is likely to trigger 


\section{HUMANS ?}

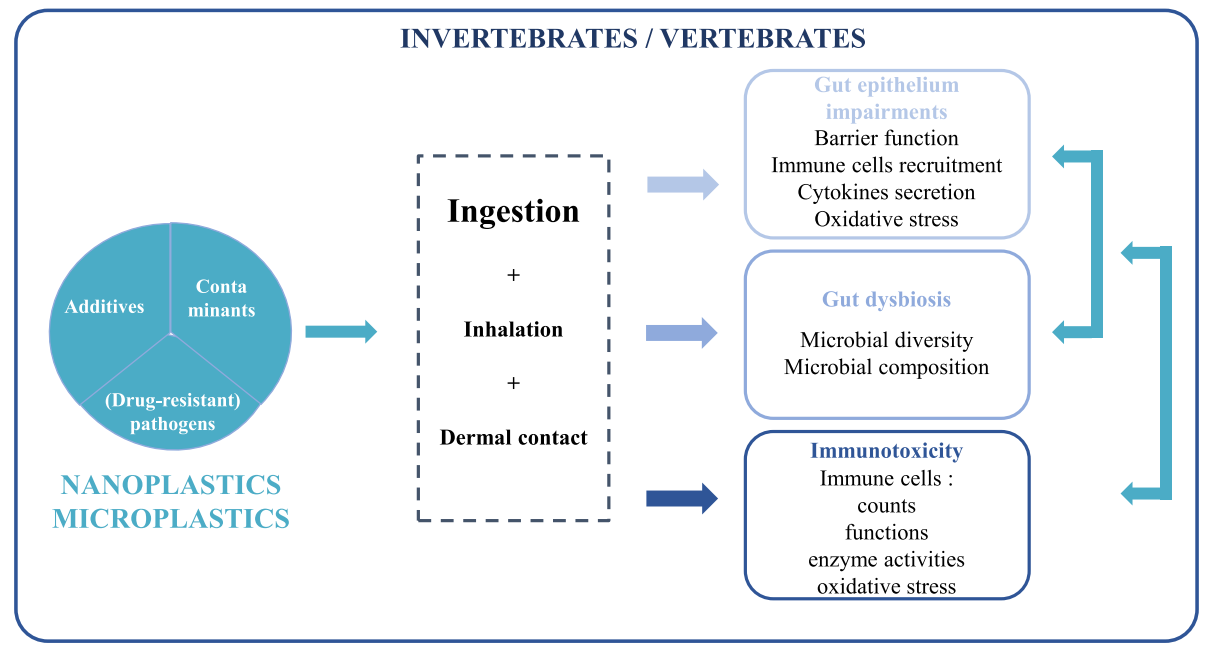

Scheme 4 Overview of the potential effects of nano- and microplastic contamination on intestinal health and the immune response

changes in the gut microbiota and activation of the immune system, although this field has not yet been explored.

\section{Conclusions}

The gut epithelium encounters a broad range of plastics. Faced with this complexity, we still have too few data on the amounts and features of ingested plastics. Analytical limitations on the detection of particles sizing few $\mu \mathrm{m}$ mean that the environmental exposure data relates to micro-size plastics only. Moreover, these exposure data are subject to debate because of the limited number of studies of food products, poor data quality (due to contamination, for example), and the absence of data on small particles [36, 134]. Furthermore, interstudy comparisons are not valid because of the lack of standardized technical methods for collection and analysis. Today's available data give us a few clues about the plastic pollutants in drinking water and in a small number of food products. Larger studies of plastics in the general diets, (i.e. providing a realistic estimate of overall oral contamination by plastics) are still lacking. With regards to this challenge, we suggest that research should initially focus on the microplastics present in human stools. This strategy is particularly useful for identifying the plastics that exert their harmful effects via direct contact with the intestinal mucosa. Furthermore, it is essential to study the nano- and microplastics that cross the intestinal barrier; even small quantities of translocated plastic may be as dangerous as or even more dangerous than plastics excreted in the stools. Lastly, in view of the recent literature on the effects of particulate matter in the atmosphere, the impact of airborne microplastics on the intestine should also be assessed [135-137].
To the best of our knowledge, the intestinal and immunotoxic effects of nanoplastic ingestion by mammals have never been studied. However, ingestion of non-plastic nanoparticles is known to have many harmful effects. For example, ingestion of $\mathrm{TiO}_{2}$ nanoparticles by mammals impairs intestinal and systemic immune homeostasis and induces variations in the gut microbiota and gut-associated metabolism [138, 139]. One can therefore reasonably hypothesize that contamination of the diet by some nanoplastics is likely to harm intestinal and immune systems; this topic requires more attention. Furthermore, the microplastics most frequently studied for their in vivo effects are PS and (to a lesser extent) PP: more efforts are required for PP and PET, the two most abundant microplastics in human feces.

Despite the lack of data on plastic levels in the human diet, it is clear that plastics contaminate water and the food chain; the toxicological effects of certain types and shapes of microplastics are now starting to be assessed. The current data are insufficient and do not allow robust scientific conclusions to be drawn for humans in general and intestinal health in particular. In this respect, the lack of reliable data on human dietary exposure means that relevant doses have yet to be defined. Furthermore, the effects of chronic exposure to microplastics appear to be very variable and dependent on the latter's type and shape. It is also very likely that the effects of a cocktail of microplastics (as encountered in real life) are different from those of individual components - further complicating the problem. Likewise, the biological relevance of the research results - notably concerning the impact on the immune system - would be increased by studies of nano- and microplastics bearing biofilms. However, most of the literature studies suggest that 
nano- and microplastics have several effects on intestine: the disturbance of intestinal homeostasis, alterations in gut permeability, and changes in the recruitment of immune cells or in levels of cytokine secretion. The intestinal dysbiosis which has been observed following microplastic ingestion, sometimes differs from one study to another but reflects the deregulation of a crucial parameter for host defense, intestinal metabolism and inflammation. The immune system's susceptibility to plastics constitutes an additional threat to health.

In conclusion, a growing body of evidence shows that the omnipresence of plastics in our daily life is associated with chronic, evolving exposure to microplastics. Furthermore, many animal experiments suggest that the ingestion of microplastics disrupts essential intestinal functions, such as the gut barrier function and regulation of the gut microbiota (Scheme 4). Due to the multifunctional nature of the intestinal system, these plasticassociated disruptions may promote immune, inflammatory and metabolic disorders and therefore warrant further investigation.

\section{Acknowledgements}

Not applicable.

\section{Authors' contributions}

$\mathrm{NH}$ was involved in the initial write-up of the background and gut microbiota sections of the manuscript. $\mathrm{NH}$ created part of the schemes and laid out part of the Tables. MB-M double-checked the literature search results and revised the draft provided by $\mathrm{NH}$. MB-M performed the literature searches and wrote the others sections of the review. NH and MB-M read and approved the final manuscript.

\section{Authors' information}

Not applicable.

\section{Funding}

The authors thank the Hauts de France Regional Council and the french association François Aupetit for their financial support.

\section{Availability of data and materials}

Not applicable.

\section{Ethics approval and consent to participate}

Not applicable.

\section{Consent for publication}

Not applicable.

\section{Competing interests}

The authors declare that they have no competing interests.

Received: 25 June 2020 Accepted: 26 October 2020

Published online: 12 November 2020

\section{References}

1. Wu P, Huang J, Zheng Y, Yang Y, Zhang Y, He F, et al. Environmental occurrences, fate, and impacts of microplastics. Ecotoxicol Environ Saf. 2019; 184:109612

2. Publications :: PlasticsEurope [Internet]. [cited 2020 Sep 7]. Available from: https://www.plasticseurope.org/fr/resources/publications/1804-plasticsfacts-2019.

3. Alimba CG, Faggio C. Microplastics in the marine environment: current trends in environmental pollution and mechanisms of toxicological profile. Environ Toxicol Pharmacol. 2019;68:61-74.
4. Lambert S, Wagner M. Microplastics are contaminants of emerging concern in freshwater environments: an overview. Freshw Microplastics. Cham: Springer; 2018. p. 1-23.

5. Peeken I, Primpke S, Beyer B, Gütermann J, Katlein C, Krumpen T, et al. Arctic Sea ice is an important temporal sink and means of transport for microplastic. Nat Commun. 2018;9:1505.

6. Xu B, Liu F, Cryder Z, Huang D, Lu Z, He Y, et al. Microplastics in the soil environment: occurrence, risks, interactions and fate - a review. Crit Rev Environ Sci Technol Taylor \& Francis. 2019;0:1-48.

7. Wang J, Liu X, Li Y, Powell T, Wang X, Wang G, et al. Microplastics as contaminants in the soil environment: a mini-review. Sci Total Environ. 2019; 691:848-57.

8. Corradini F, Meza P, Equiluz R, Casado F, Huerta-Lwanga E, Geissen V. Evidence of microplastic accumulation in agricultural soils from sewage sludge disposal. Sci Total Environ. 2019;671:411-20.

9. Eriksen M, Lebreton LCM, Carson HS, Thiel M, Moore CJ, Borerro JC, et al. lastic Pollution in the World's Oceans: More than 5 Trillion Plastic Pieces Weighing over 250,000 Tons Afloat at Sea. PLOS ONE. Public Libr Sci. 2014;9: e111913.

10. Schwarz AE, Ligthart TN, Boukris E, van Harmelen T. Sources, transport, and accumulation of different types of plastic litter in aquatic environments: a review study. Mar Pollut Bull. 2019;143:92-100.

11. Jambeck JR, Geyer R, Wilcox C, Siegler TR, Perryman M, Andrady A, et al. Plastic waste inputs from land into the ocean. Sci Am Assoc Advancement Sci. 2015;347:768-71.

12. Bouwmeester H, Hollman PCH, Peters RJB. Potential health impact of environmentally released micro- and Nanoplastics in the human food production chain: experiences from Nanotoxicology. Environ Sci Technol Am Chem Soc. 2015;49:8932-47.

13. Rochman CM, Kross SM, Armstrong JB, Bogan MT, Darling ES, Green SJ, et al. Scientific evidence supports a ban on microbeads. Environ Sci Technol. 2015;49:10759-61.

14. Prata JC. Airborne microplastics: consequences to human health? Environ Pollut. 2018;234:115-26.

15. Chen G, Feng Q, Wang J. Mini-review of microplastics in the atmosphere and their risks to humans. Sci Total Environ. Elsevier. 2020;703:135504.

16. Wright SL, Ulke J, Font A, Chan KLA, Kelly FJ. Atmospheric microplastic deposition in an urban environment and an evaluation of transport. Environ Int. 2020;136:105411.

17. Liu K, Wang X, Fang T, Xu P, Zhu L, Li D. Source and potential risk assessment of suspended atmospheric microplastics in Shanghai. Sci Total Environ. 2019;675:462-71.

18. Allen $S$, Allen D, Phoenix VR, Le Roux G, Durántez Jiménez $P$, Simonneau $A$, et al. Atmospheric transport and deposition of microplastics in a remote mountain catchment. Nat Geosci Nature Publishing Group. 2019;12:339-44

19. Vianello A, Jensen RL, Liu L, Vollertsen J. Simulating human exposure to indoor airborne microplastics using a Breathing Thermal Manikin. Sci Rep Nat Publ Group. 2019;9:8670.

20. Zhang Q, Zhao Y, Du F, Cai H, Wang G, Shi H. Microplastic fallout in different indoor environments. Environ Sci Technol Am Chem Soc. 2020;54: 6530-9.

21. Prata JC, da Costa JP, Lopes I, Duarte AC, Rocha-Santos T. Environmental exposure to microplastics: An overview on possible human health effects. Sci Total Environ. 2020;702:134455.

22. Andrady AL, Neal MA. Applications and societal benefits of plastics. Philos Trans R Soc Lond Ser B Biol Sci. 2009:364:1977-84.

23. Rochman CM, Brookson C, Bikker J, Djuric N, Earn A, Bucci K, et al Rethinking microplastics as a diverse contaminant suite. Environ Toxicol Chem. 2019:38:703-11.

24. Lebreton L, Slat B, Ferrari F, Sainte-Rose B, Aitken J, Marthouse R, et al. Evidence that the Great Pacific Garbage Patch is rapidly accumulating plastic. Sci Rep Nat Publ Group. 2018;8:4666

25. Thompson RC, Olsen Y, Mitchell RP, Davis A, Rowland SJ, John AWG, et al. Lost at sea: where is all the plastic? Sci Am Assoc Advanc Sci. 2004;304:838.

26. Toussaint B, Raffael B, Angers-Loustau A, Gilliland D, Kestens V, Petrillo $M$, et al. Review of micro- and nanoplastic contamination in the food chain. Food Addit Contam Part Chem Anal Control Expo Risk Assess. 2019;36:639-73

27. Gigault J, ter Halle A, Baudrimont M, Pascal P-Y, Gauffre F, Phi T-L, et al. Current opinion: what is a nanoplastic? Environ Pollut. 2018;235:1030-4. 
28. Lehner R, Weder C, Petri-Fink A, Rothen-Rutishauser B. Emergence of Nanoplastic in the environment and possible impact on human health. Environ Sci Technol. 2019;53:1748-65.

29. Schwaferts C, Niessner R, Elsner M, Ivleva NP. Methods for the analysis of submicrometer- and nanoplastic particles in the environment. TrAC Trends Anal Chem. 2019;112:52-65.

30. Koelmans B, Pahl S, Backhaus T, Bessa F, van Calster G, Contzen N, et al. A scientific perspective on microplastics in nature and society. SAPEA; 2019.

31. Koelmans AA, Mohamed Nor NH, Hermsen E, Kooi M, Mintenig SM, De France J. Microplastics in freshwaters and drinking water: critical review and assessment of data quality. Water Res. 2019;155:410-22.

32. Danopoulos E, Twiddy M, Rotchell JM. Microplastic contamination of drinking water: A systematic review. PloS One. Public Library of Science San Francisco, CA USA. 2020;15:e0236838.

33. Novotna K, Cermakova L, Pivokonska L, Cajthaml T, Pivokonsky M. Microplastics in drinking water treatment - current knowledge and research needs. Sci Total Environ. 2019;667:730-40.

34. Kosuth M, Mason SA, Wattenberg EV. Anthropogenic contamination of tap water, beer, and sea salt. PLOS ONE Public Libr Sci. 2018;13:e0194970.

35. Tong $H$, Jiang $Q, H u X$, Zhong X. Occurrence and identification of microplastics in tap water from China. Chemosphere. 2020;252:126493.

36. Welle F, Franz R. Microplastic in bottled natural mineral water literature review and considerations on exposure and risk assessment. Food Addit Contam Part Chem Anal Control Expo Risk Assess. 2018;35: 2482-92.

37. Oßmann BE, Sarau G, Holtmannspötter H, Pischetsrieder M, Christiansen SH, Dicke W. Small-sized microplastics and pigmented particles in bottled mineral water. Water Res. 2018;141:307-16.

38. Schymanski D, Goldbeck C, Humpf H-U, Fürst P. Analysis of microplastics in water by micro-Raman spectroscopy: release of plastic particles from different packaging into mineral water. Water Res. 2018;129:154-62.

39. van Raamsdonk LWD, van der Zande M, Koelmans AA, Hoogenboom RLAP, Peters RJB, Groot MJ, et al. Current insights into monitoring, bioaccumulation, and potential health effects of microplastics present in the food chain. Foods Basel Switz. 2020;9:72.

40. Kankanige D, Babel S. Smaller-sized micro-plastics (MPs) contamination in single-use PET-bottled water in Thailand. Sci Total Environ. Elsevier. 2020; 717:137232.

41. Van Cauwenberghe $L$, Janssen CR. Microplastics in bivalves cultured for human consumption. Environ Pollut Barking Essex 1987. 2014;193:65-70.

42. Smith M, Love DC, Rochman CM, Neff RA. Microplastics in seafood and the implications for human health. Curr Environ Health Rep. 2018;5:375-86.

43. Lusher A, Hollman PCH, Mendoza-Hill J. Microplastics in fisheries and aquaculture: status of knowledge on their occurrence and implications for aquatic organisms and food safety. Rome: Food and Agriculture Organization of the United Nations; 2017.

44. Hantoro I, Löhr AJ, Van Belleghem FGAJ, Widianarko B, Ragas AMJ. Microplastics in coastal areas and seafood: implications for food safety. Food Addit Contam Part Chem Anal Control Expo Risk Assess. 2019;36: 674-711.

45. Liebezeit G, Liebezeit E. Non-pollen particulates in honey and sugar. Food Addit Contam Part A Taylor \& Francis. 2013;30:2136-40.

46. Yang D, Shi H, Li L, Li J, Jabeen K, Kolandhasamy P. Microplastic pollution in table salts from China. Environ Sci Technol. 2015;49:13622-7.

47. Iñiguez ME, Conesa JA, Fullana A. Microplastics in Spanish table salt. Sci Rep. 2017;7:8620

48. Karami A, Golieskardi A, Ho YB, Larat V, Salamatinia B. Microplastics in eviscerated flesh and excised organs of dried fish. Sci Rep. 2017;7:5473.

49. Gündoğdu S. Contamination of table salts from Turkey with microplastics. Food Addit Contam Part Chem Anal Control Expo Risk Assess. 2018;35: 1006-14.

50. Liebezeit G, Liebezeit E. Synthetic particles as contaminants in German beers. Food Addit Contam Part A. Taylor \& Francis. 2014;31:1574-8.

51. Kutralam-Muniasamy G, Pérez-Guevara F, Elizalde-Martínez I, Shruti VC. Branded milks - are they immune from microplastics contamination? Sci Total Environ. 2020;714:136823.

52. Gasperi J, Wright SL, Dris R, Collard F, Mandin C, Guerrouache M, et al. Microplastics in air: are we breathing it in? Curr Opin Environ Sci Health. 2018;1:1-5.

53. Strand J. Contents of polyethylene microplastic in some selected personal care products in Denmark; 2014.
54. Lei K, Qiao F, Liu Q, Wei Z, Qi H, Cui S, et al. Microplastics releasing from personal care and cosmetic products in China. Mar Pollut Bull. 2017;123: 122-6.

55. Leslie HA. Review of microplastics in cosmetics. IVM Inst Environ Stud. 2014; 476:1-33.

56. Yurtsever M. Tiny, shiny, and colorful microplastics: are regular glitters a significant source of microplastics? Mar Pollut Bull. 2019;146:678-82.

57. Hernandez LM, Yousefi N, Tufenkji N. Are there Nanoplastics in your personal care products? Environ Sci Technol Lett. 2017:4:280-5.

58. Deng $Y$, Zhang $Y$, Lemos $B$, Ren $\mathrm{H}$. Tissue accumulation of microplastics in mice and biomarker responses suggest widespread health risks of exposure. Sci Rep. 2017;7:46687.

59. Qiao R, Deng Y, Zhang S, Wolosker MB, Zhu Q, Ren H, et al. Accumulation of different shapes of microplastics initiates intestinal injury and gut microbiota dysbiosis in the gut of zebrafish. Chemosphere. 2019;236:124334

60. Jin Y, Lu L, Tu W, Luo T, Fu Z. Impacts of polystyrene microplastic on the gut barrier, microbiota and metabolism of mice. Sci Total Environ. 2019;649: 308-17.

61. Deng Y, Zhang Y, Qiao R, Bonilla MM, Yang X, Ren H, et al. Evidence that microplastics aggravate the toxicity of organophosphorus flame retardants in mice (Mus musculus). J Hazard Mater. 2018;357:348-54.

62. Hillery A, Jani P, Florence A. Comparative, quantitative study of lymphoid and non-lymphoid uptake of $60 \mathrm{~nm}$ polystyrene particles. J Drug Target Taylor \& Francis. 1994;2:151-6.

63. EFSA. Presence of microplastics and nanoplastics in food, with particular focus on seafood. EFSA J. 2016;14:e04501.

64. Powell JJ, Faria N, Thomas-McKay E, Pele LC. Origin and fate of dietary nanoparticles and microparticles in the gastrointestinal tract. J Autoimmun. 2010;34:J226-33.

65. Coméra C, Cartier C, Gaultier E, Catrice O, Panouille Q, Hamdi SE, et al. Jejunal villus absorption and paracellular tight junction permeability are major routes for early intestinal uptake of food-grade TiO 2 particles: an in vivo and ex vivo study in mice. Part Fibre Toxicol BioMed Central. 2020;17:1-15.

66. Smith MW, Thomas NW, Jenkins PG, Miller NG, Cremaschi D, Porta C. Selective transport of microparticles across Peyer's patch follicle-associated M cells from mice and rats. Exp Physiol. 1995;80:735-43.

67. Galloway TS. Micro-and nano-plastics and human health. Mar Anthropog Litter. Cham: Springer; 2015. p. 343-66.

68. Carr KE, Smyth SH, McCullough MT, Morris JF, Moyes SM. Morphological aspects of interactions between microparticles and mammalian cells: intestinal uptake and onward movement. Prog Histochem Cytochem Elsevier. 2012;46:185-252.

69. Prüst M, Meijer J, Westerink RHS. The plastic brain: neurotoxicity of microand nanoplastics. Part Fibre Toxicol BioMed Central. 2020;17:1-16.

70. Smith JRH, Etherington G, Shutt AL, Youngman MJ. A study of aeroso deposition and clearance from the human nasal passage. Ann Occup Hyg Oxford University Press. 2002;46:309-13.

71. Asgharian B, Hofmann W, Miller FJ. Mucociliary clearance of insoluble particles from the tracheobronchial airways of the human lung. J Aerosol Sci Elsevier. 2001;32:817-32.

72. Enaud R, Prevel R, Ciarlo E, Beaufils F, Wieërs G, Guery B, et al. The gut-lung axis in health and respiratory diseases: a place for inter-organ and interkingdom crosstalks. Front cell infect Microbiol. Frontiers. 2020;10:9.

73. Bachmanov AA, Reed DR, Beauchamp GK, Tordoff MG. Food intake, water intake, and drinking spout side preference of 28 mouse strains. Behav Genet. 2002;32:435-43.

74. Lei L, Wu S, Lu S, Liu M, Song Y, Fu Z, et al. Microplastic particles cause intestinal damage and other adverse effects in zebrafish Danio rerio and nematode Caenorhabditis elegans. Sci Total Environ. 2018;619-620:1-8.

75. Wang Y, Mao Z, Zhang M, Ding G, Sun J, Du M, et al. The uptake and elimination of polystyrene microplastics by the brine shrimp, Artemia parthenogenetica, and its impact on its feeding behavior and intestinal histology. Chemosphere. 2019;234:123-31.

76. Paul-Pont I, Lacroix C, González Fernández C, Hégaret H, Lambert C, Le Goïc $\mathrm{N}$, et al. Exposure of marine mussels Mytilus spp. to polystyrene microplastics: toxicity and influence on fluoranthene bioaccumulation. Environ Pollut. 2016;216:724-37.

77. Brandts I, Teles M, Gonçalves AP, Barreto A, Franco-Martinez L, Tvarijonaviciute $A$, et al. Effects of nanoplastics on Mytilus galloprovincialis after individual and combined exposure with carbamazepine. Sci Total Environ. 2018;643:775-84. 
78. Revel M, Lagarde F, Perrein-Ettajani $H$, Bruneau M, Akcha F, Sussarellu R, et al. Tissue-Specific Biomarker Responses in the Blue Mussel Mytilus spp. Exposed to a Mixture of Microplastics at Environmentally Relevant Concentrations. Front Environ Sci. 2019;7. [cited 2020 Aug 13]. https://doi. org/10.3389/fenvs.2019.00033/full.

79. Ašmonaitè $G$, Sundh $H$, Asker $N$, Carney $A B$. Rainbow trout maintain intestinal transport and barrier functions following exposure to polystyrene microplastics. Environ Sci Technol ACS Publications. 2018;52: 14392-401.

80. Huang J-N, Wen B, Zhu J-G, Zhang Y-S, Gao J-Z, Chen Z-Z. Exposure to microplastics impairs digestive performance, stimulates immune response and induces microbiota dysbiosis in the gut of juvenile guppy (Poecilia reticulata). Sci Total Environ. 2020;733:138929.

81. Ahrendt C, Perez-Venegas DJ, Urbina M, Gonzalez C, Echeveste P, Aldana M, et al. Microplastic ingestion cause intestinal lesions in the intertidal fish Girella laevifrons. Mar Pollut Bull. 2020;151:110795.

82. Gu H, Wang S, Wang X, Yu X, Hu M, Huang W, et al. Nanoplastics impair the intestinal health of the juvenile large yellow croaker Larimichthys crocea. J Hazard Mater. 2020;397:122773.

83. Kang H-M, Byeon E, Jeong H, Kim M-S, Chen Q, Lee J-S. Different effects of nano- and microplastics on oxidative status and gut microbiota in the marine medaka Oryzias melastigma. J Hazard Mater. 2020;124207.

84. Jin Y, Xia J, Pan Z, Yang J, Wang W, Fu Z. Polystyrene microplastics induce microbiota dysbiosis and inflammation in the gut of adult zebrafish. Environ Pollut Barking Essex 1987. 2018;235:322-9.

85. Qiao R, Sheng C, Lu Y, Zhang Y, Ren H, Lemos B. Microplastics induce intestinal inflammation, oxidative stress, and disorders of metabolome and microbiome in zebrafish. Sci Total Environ. 2019;662:246-53.

86. Gu W, Liu S, Chen L, Liu Y, Gu C, Ren H-Q, et al. Single-cell RNA sequencing reveals size-dependent effects of polystyrene microplastics on immune and secretory cell populations from Zebrafish intestines. Environ Sci Technol. 2020:54:3417-27.

87. Pedà C, Caccamo L, Fossi MC, Gai F, Andaloro F, Genovese L, et al. Intestinal alterations in European sea bass Dicentrarchus labrax (Linnaeus, 1758) exposed to microplastics: preliminary results. Environ Pollut. 2016;212:251-6.

88. Espinosa C, Esteban MÁ, Cuesta A. Dietary administration of PVC and PE microplastics produces histological damage, oxidative stress and immunoregulation in European sea bass (Dicentrarchus labrax L.). Fish Shellfish Immunol. 2019;95:574-83.

89. Jabeen K, Li B, Chen Q, Su L, Wu C, Hollert H, et al. Effects of virgin microplastics on goldfish (Carassius auratus). Chemosphere. 2018;213: 323-32.

90. Limonta G, Mancia A, Benkhalqui A, Bertolucci C, Abelli L, Fossi MC, et al. Microplastics induce transcriptional changes, immune response and behavioral alterations in adult zebrafish. Sci Rep. 2019;9:15775.

91. Lu L, Wan Z, Luo T, Fu Z, Jin Y. Polystyrene microplastics induce gut microbiota dysbiosis and hepatic lipid metabolism disorder in mice. Sci Total Environ. 2018;631-632:449-58.

92. Stock V, Böhmert L, Lisicki E, Block R, Cara-Carmona J, Pack LK, et al. Uptake and effects of orally ingested polystyrene microplastic particles in vitro and in vivo. Arch Toxicol. 2019;93:1817-33.

93. Li B, Ding Y, Cheng X, Sheng D, Xu Z, Rong $Q$, et al. Polyethylene microplastics affect the distribution of gut microbiota and inflammation development in mice. Chemosphere. 2020;244:125492.

94. Deng $Y$, Yan Z, Shen R, Wang M, Huang Y, Ren H, et al. Microplastics release phthalate esters and cause aggravated adverse effects in the mouse gut. Environ Int. 2020;143:105916

95. Caruso G, Pedà C, Cappello S, Leonardi M, La Ferla R, Lo Giudice A, et al. Effects of microplastics on trophic parameters, abundance and metabolic activities of seawater and fish gut bacteria in mesocosm conditions. Environ Sci Pollut Res. 2018;25:30067-83.

96. Chae Y, Kim D, Choi M-J, Cho Y, An Y-J. Impact of nano-sized plastic on the nutritional value and gut microbiota of whiteleg shrimp Litopenaeus vannamei via dietary exposure. Environ Int. 2019;130:104848.

97. Zhu D, Chen Q-L, An X-L, Yang X-R, Christie P, Ke X, et al. Exposure of soil collembolans to microplastics perturbs their gut microbiota and alters their isotopic composition. Soil Biol Biochem. 2018;116:302-10.

98. Ju H, Zhu D, Qiao M. Effects of polyethylene microplastics on the gut microbial community, reproduction and avoidance behaviors of the soil springtail, Folsomia candida. Environ Pollut. 2019;247:890-7.
99. Liu Z, Yu P, Cai M, Wu D, Zhang M, Chen M, et al. Effects of microplastics on the innate immunity and intestinal microflora of juvenile Eriocheir sinensis. Sci Total Environ. 2019;685:836-46.

100. Wan Z, Wang C, Zhou J, Shen M, Wang X, Fu Z, et al. Effects of polystyrene microplastics on the composition of the microbiome and metabolism in larval zebrafish. Chemosphere. 2019;217:646-58.

101. Luo T, Wang C, Pan Z, Jin C, Fu Z, Jin Y. Maternal polystyrene microplastic exposure during gestation and lactation altered metabolic homeostasis in the dams and their F1 and F2 offspring. Environ Sci Technol. 2019;53: 10978-92.

102. Sadler DE, Brunner FS, Plaistow SJ. Temperature and clone-dependent effects of microplastics on immunity and life history in Daphnia magna. Environ Pollut Barking Essex 1987. 2019;255:113178.

103. Auguste M, Balbi T, Ciacci C, Canonico B, Papa S, Borello A, et al. Shift in Immune Parameters After Repeated Exposure to Nanoplastics in the Marine Bivalve Mytilus. Front Immunol. 2020;11. [cited 2020 Aug 10]. https://doi. org/10.3389/fimmu.2020.00426/full?report=reader.

104. Auguste M, Lasa A, Balbi T, Pallavicini A, Vezzulli L, Canesi L. Impact of nanoplastics on hemolymph immune parameters and microbiota composition in Mytilus galloprovincialis. Mar Environ Res. 2020;159: 105017.

105. Murano C, Agnisola C, Caramiello D, Castellano I, Casotti R, Corsi I, et al. How sea urchins face microplastics: uptake, tissue distribution and immune system response. Environ Pollut. 2020;264:114685.

106. Revel M, Yakovenko N, Caley T, Guillet C, Châtel A, Mouneyrac C. Accumulation and immunotoxicity of microplastics in the estuarine worm Hediste diversicolor in environmentally relevant conditions of exposure. Environ Sci Pollut Res Int. 2020;27:3574-83.

107. Revel M, Châtel A, Perrein-Ettajani H, Bruneau M, Akcha F, Sussarellu R, et al. Realistic environmental exposure to microplastics does not induce biological effects in the Pacific oyster Crassostrea gigas. Mar Pollut Bull. 2020;150:110627.

108. Green DS, Colgan TJ, Thompson RC, Carolan JC. Exposure to microplastics reduces attachment strength and alters the haemolymph proteome of blue mussels (Mytilus edulis). Environ Pollut Barking Essex 1987. 2019;246:423-34.

109. Shi W, Han Y, Sun S, Tang Y, Zhou W, Du X, et al. Immunotoxicities of microplastics and sertraline, alone and in combination, to a bivalve species: size-dependent interaction and potential toxication mechanism. J Hazard Mater. 2020;396:122603.

110. Tang Y, Rong J, Guan X, Zha S, Shi W, Han Y, et al. Immunotoxicity of microplastics and two persistent organic pollutants alone or in combination to a bivalve species. Environ Pollut Barking Essex 1987 2020:258:113845.

111. Greven A-C, Merk T, Karagöz F, Mohr K, Klapper M, Jovanović B, et al. Polycarbonate and polystyrene nanoplastic particles act as stressors to the innate immune system of fathead minnow (Pimephales promelas). Environ Toxicol Chem. 2016:35:3093-100.

112. Brandts I, Teles M, Tvarijonaviciute A, Pereira ML, Martins MA, Tort L, et al. Effects of polymethylmethacrylate nanoplastics on Dicentrarchus labrax. Genomics. 2018;110:435-41.

113. Banaee M, Soltanian S, Sureda A, Gholamhosseini A, Haghi BN, Akhlaghi M, et al. Evaluation of single and combined effects of cadmium and microplastic particles on biochemical and immunological parameters of common carp (Cyprinus carpio). Chemosphere. 2019;236:124335.

114. Espinosa C, Cuesta A, Esteban MÁ. Effects of dietary polyvinylchloride microparticles on general health, immune status and expression of several genes related to stress in gilthead seabream (Sparus aurata L.). Fish Shellfish Immunol. 2017:68:251-9.

115. Espinosa C, García Beltrán JM, Esteban MA, Cuesta A. In vitro effects of virgin microplastics on fish head-kidney leucocyte activities. Environ Pollut Barking Essex 1987. 2018;235:30-8.

116. Park E-J, Han J-S, Park E-J, Seong E, Lee G-H, Kim D-W, et al. Repeated-oral dose toxicity of polyethylene microplastics and the possible implications on reproduction and development of the next generation. Toxicol Lett. 2020; 324:75-85.

117. Mancia A, Chenet T, Bono G, Geraci ML, Vaccaro C, Munari C, et al. Adverse effects of plastic ingestion on the Mediterranean small-spotted catshark (Scyliorhinus canicula). Mar Environ Res. 2020:155:104876.

118. Teuten EL, Saquing JM, Knappe DRU, Barlaz MA, Jonsson S, Björn A, et al. Transport and release of chemicals from plastics to the environment and to wildlife. Philos Trans R Soc Lond Ser B Biol Sci. 2009;364:2027-45. 
119. Global Pollution Map [ :: International Pellet Watch [Internet]. [cited 2020 Oct 22]. Available from: http://www.pelletwatch.org/maps/map-1.html.

120. Global Pollution Map [ :: International Pellet Watch [Internet]. [cited 2020 Oct 22]. Available from: http://www.pelletwatch.org/maps/map-5.html.

121. Zhou W, Han Y, Tang Y, Shi W, Du X, Sun S, et al. Microplastics aggravate the bioaccumulation of two waterborne veterinary antibiotics in an edible bivalve species: potential mechanisms and implications for human health. Environ Sci Technol American Chemical Society. 2020;54:8115-22.

122. Scopetani C, Cincinelli A, Martellini T, Lombardini E, Ciofini A, Fortunati A, et al. Ingested microplastic as a two-way transporter for PBDEs in Talitrus saltator. Environ Res. 2018;167:411-7.

123. Wen B, Jin S-R, Chen Z-Z, Gao J-Z, Liu Y-N, Liu J-H, et al. Single and combined effects of microplastics and cadmium on the cadmium accumulation, antioxidant defence and innate immunity of the discus fish (Symphysodon aequifasciatus). Environ Pollut. 2018:243:462-71.

124. Syberg K, Nielsen A, Khan FR, Banta GT, Palmqvist A, Jepsen PM. Microplastic potentiates triclosan toxicity to the marine copepod Acartia tonsa (Dana). J Toxicol Environ Health A. 2017;80:1369-71.

125. Tang Y, Zhou W, Sun S, Du X, Han Y, Shi W, et al. Immunotoxicity and neurotoxicity of bisphenol a and microplastics alone or in combination to a bivalve species. Tegillarca granosa Environ Pollut. 2020;265:115115.

126. Sun S, Shi W, Tang Y, Han Y, Du X, Zhou W, et al. Immunotoxicity of petroleum hydrocarbons and microplastics alone or in combination to a bivalve species: synergic impacts and potential toxication mechanisms. Sci Total Environ. 2020;138852. in press.

127. Bellas J, Gil I. Polyethylene microplastics increase the toxicity of chlorpyrifos to the marine copepod Acartia tonsa. Environ Pollut. 2020;260:114059.

128. Bowley J, Baker-Austin C, Porter A, Hartnell R, Lewis C. Oceanic hitchhikersassessing pathogen risks from marine microplastic. Trends Microbiol. Elsevier. 2020. https://doi.org/10.1016/j.tim.2020.06.011.

129. Yang Y, Liu W, Zhang Z, Grossart H-P, Gadd GM. Microplastics provide new microbial niches in aquatic environments. Appl Microbiol Biotechnol. Springer. 2020;104:6501-11.

130. Wu X, Pan J, Li M, Li Y, Bartlam M, Wang Y. Selective enrichment of bacterial pathogens by microplastic biofilm. Water Res. Elsevier. 2019;165:114979.

131. Zhang Y, Lu J, Wu J, Wang J, Luo Y. Potential risks of microplastics combined with superbugs: Enrichment of antibiotic resistant bacteria on the surface of microplastics in mariculture system. Ecotoxicol Environ Saf. Elsevier. 2020;187:109852.

132. Md I, Das KR, Naik MM. Co-selection of multi-antibiotic resistance in bacterial pathogens in metal and microplastic contaminated environments: An emerging health threat. Chemosphere. 2019;215:846-57.

133. Li L-L, Amara R, Souissi S, Dehaut A, Duflos G, Monchy S. Impacts of microplastics exposure on mussel (Mytilus edulis) gut microbiota. Sci Total Environ. 2020;745:141018

134. Weis JS. Aquatic Microplastic Research—A Critique and Suggestions for the Future. Water. Multidisciplinary Digital Publishing Institute. 2020;12:1475.

135. Vignal $C$, Pichavant M, Alleman LY, Djouina M, Dingreville F, Perdrix E, et al. Effects of urban coarse particles inhalation on oxidative and inflammatory parameters in the mouse lung and colon. Part Fibre Toxicol. 2017;14:46.

136. Li X, Cui J, Yang H, Sun H, Lu R, Gao N, et al. Colonic injuries induced by inhalational exposure to particulate-matter air pollution. Adv Sci Weinh Baden-Wurtt Ger. 2019;6:1900180

137. Li X, Sun H, Li B, Zhang X, Cui J, Yun J, et al. Probiotics ameliorate Colon epithelial injury induced by ambient ultrafine particles exposure. Adv Sci Weinh Baden-Wurtt Ger. 2019;6:1900972.

138. Bettini S, Boutet-Robinet E, Cartier C, Coméra C, Gaultier E, Dupuy J, et al. Food-grade TiO2 impairs intestinal and systemic immune homeostasis, initiates preneoplastic lesions and promotes aberrant crypt development in the rat colon. Sci Rep. 2017;7:40373.

139. Chen Z, Han S, Zhou D, Zhou S, Jia G. Effects of oral exposure to titanium dioxide nanoparticles on gut microbiota and gut-associated metabolism in vivo. Nanoscale. 2019;11:22398-412.

\section{Publisher's Note}

Springer Nature remains neutral with regard to jurisdictional claims in published maps and institutional affiliations.

Ready to submit your research? Choose BMC and benefit from:

- fast, convenient online submission

- thorough peer review by experienced researchers in your field

- rapid publication on acceptance

- support for research data, including large and complex data types

- gold Open Access which fosters wider collaboration and increased citations

- maximum visibility for your research: over $100 \mathrm{M}$ website views per year

At BMC, research is always in progress.

Learn more biomedcentral.com/submissions 